Article

\title{
Working through Disaster Risk Management to Support Regional Food Resilience: A Case Study in North-Eastern Australia
}

\author{
Kimberley Reis ${ }^{1, *}$, Cheryl Desha ${ }^{1}\left(\mathbb{D}\right.$, Sioux Campbell $^{2}$ and Prudence Liddy ${ }^{2}$ \\ 1 Cities Research Institute, School of Engineering and Built Environment, Griffith University, \\ Brisbane, QLD 4111, Australia; c.desha@griffith.edu.au \\ 2 Disaster Management Unit, Cairns Regional Council, P.O. Box 359, Cairns, QLD 4870, Australia; \\ s.campbell@cairns.qld.gov.au (S.C.); prueliddy@gmail.com (P.L.) \\ * Correspondence: k.reis@griffith.edu.au
}

check for updates

Citation: Reis, K.; Desha, C.; Campbell, S.; Liddy, P. Working through Disaster Risk Management to Support Regional Food Resilience: A Case Study in North-Eastern Australia. Sustainability 2022, 14, 2466 https://doi.org/10.3390/su14042466 Academic Editors: Michael A. Long, Margaret Anne Defeyter and Paul B. Stretesky

Received: 1 December 2021 Accepted: 15 February 2022 Published: 21 February 2022

Publisher's Note: MDPI stays neutral with regard to jurisdictional claims in published maps and institutional affiliations.

Copyright: (c) 2022 by the authors. Licensee MDPI, Basel, Switzerland. This article is an open access article distributed under the terms and conditions of the Creative Commons Attribution (CC BY) license (https:// creativecommons.org/licenses/by/ $4.0 /)$.

\begin{abstract}
As a consequence of disasters such as pandemics and severe weather events, Australian communities often face 'food shortages' resulting from the reduced availability of food and reduced access to available food. These food shortages can be acutely felt by vulnerable populations, comprising people in communities who are already dealing with social or economic disadvantages. Despite growing calls to ensure food access for everyone during and following disasters, efforts are still largely ad hoc, champion based and highly variable in their reliability and quality of supply. There is also a disconnect between disaster-related food relief and improving business continuity towards local economic resilience. This study sought to tackle these challenges by exploring how 'local food access' could be integrated within disaster management mechanisms, to support the most vulnerable and also contribute to local economic resilience. This paper discusses the findings of a study undertaken in Cairns, a north-eastern Australian regional authority, and involves a review of disaster management planning and policy artifacts, an online survey, and semi-structured interviews with stakeholders providing care and advocacy for vulnerable populations. Synthesizing the findings, we present a disaster-management-focused 'Local Food Access Model' that connects shorter food supply chains to improved disaster response, resilience and contingency-planning agendas. Applying this model to Cairns, we conclude the multiple benefits and immediate stakeholder readiness for a virtual (online) food resilience and contingency hub, to enable the connection of local food availability and access information within existing disaster management processes. The research method used, the model, and the case-specific findings provide government decision makers with a useful process, a local food-access schematic and a case study example to support immediate improvements in disaster resilience for vulnerable populations.
\end{abstract}

Keywords: disaster resilience; vulnerable populations; food insecurity; short food supply chains; local food procurement; disaster management plans; contingency-planning agendas

\section{Introduction: Increasing Experiences of Food Insecurity}

Despite global food availability, local and regional food insecurity has existed for centuries, reflecting geographical, geopolitical and climate-related challenges to enabling sufficient food calories for life, and for all. Global aid agencies and international foreign aid efforts have long-endeavored to provide food aid to developing countries experiencing long-term and acute challenges. Supplying food to citizens and enabling access to this food is a continued challenge [1]. The United Nations Food and Agriculture Organization (UN-FAO) advises that nations should meet the needs of the most vulnerable people, as efforts to contain the pandemic have crippled economies [2].

Long, Goncalves, Stretesky and Defeyter contend that neoliberal economic assertions tend to overlook the drivers of poverty and inequality embedded in the fabric of developed 
countries and focus on the "importance of individual responsibility for personal failures rather than structural reasons associated with capitalism" [3] (p. 2). However, in recent decades, two new contexts for food insecurity in developed countries have arisen, resulting in a substantial increase in new 'first-time vulnerable' recipients of food aid, including 'wealthy' nations [4,5]. Firstly, the increasing prevalence and intensity of climate-related disasters around the world have resulted in eroded farmlands and depleted food reserves at an unprecedented scale. Secondly, local food stress has manifested during the deployment of home-based lockdowns and physical distancing directives to suppress COVID-19 outbreaks [3]. The emerging movement towards accessing local and regional food supplies is evident in papers on the social and economic impacts of COVID-19 [6-9].

Examples of these new food vulnerabilities have been documented for countries such as the United States [10], the United Kingdom [11,12], and Australia [13]. In the authors' home state of Queensland, Australia, major charities have reported increased stress in the provision of food relief over the last two years. The Australian Foodbank Hunger Report 2020 concluded that, the "demand for food relief in Queensland is rising, and is higher than ever recorded in Foodbank Queensland's 25-year history" [14] (Para 1), wherein one third of those facing hunger in 2020 have never experienced it before. These recent lived experiences of food disadvantage invite reconsideration of what is meant by the UN-FAO's reference to the 'most vulnerable', with the affected demographics ranging far beyond what has been experienced in the past.

As governments around the world work to improve the local resilience of communities to issues of essential services (such as water and energy supply) and food sufficiency, the construct of 'shared responsibility' is receiving increasing attention [15]. Considering the disaster management processes of 'prevent-prepare-respond-recover' (PPRR) [16-18], this enables local 'bottom-up' prevention and preparedness (PP) actions for social and economic wellbeing, alongside centralized 'top-down' decision making, towards improved response and recovery (RR) [19-21]. The state of Queensland is a leading example of this type of governance, which has been well documented in the state's management of more than two thirds of the Country's natural disasters for one fifth of its population, including more than AUD \$16 billion in disaster management over the last decade [22,23]. Looking ahead, the Queensland Reconstruction Authority (QRA) is prioritizing 'resilient communities', including increasing budget availability for PP activities towards mitigating the impacts of future disasters [22].

Responding to global local food insecurity challenges and our local experience of commitment to improved prevention and preparedness in the face of disasters, we asked: "How can local food access arrangements be embedded within the disaster management processes (PPRR), to support vulnerable populations?" In Northern Queensland, Cairns Regional Council is a leading local authority in identifying and building capacities for accessing locally and regionally grown food for the benefit of the most vulnerable. We sought to understand policy mechanisms that can enable local food access, and to investigate challenges and opportunities for pursuing shared responsibility pathways going forward.

The paper begins with a discussion of the policy and planning context for addressing vulnerable community resilience through disaster management. Following a summary of methods, we present the results of two workshops with council personnel and a survey of support-services personnel regarding the feasibility of enabling local food access for vulnerable populations. These data are used to discuss overall community resilience to disasters, considering the end-user needs and five strategic priorities for local government authorities within a 'Local Food Access Model'.

\section{Case Study Context: Cairns, Australia}

Australia provides an interesting example of a developed country that has, for the most part, focused its attention internationally to support 'food aid' in other countries, with comparatively brief domestic emergency-food-aid arrangements. Between the years of 2014 and 2018, Australia invested more than AUD \$103 million (USD \$74.2 million) in food 
and disaster-related projects and programs lead by the United Nations for countries in the Asia-Pacific region. As such, Australia plays a significant international and regional role in strengthening food-centered livelihoods and building social and economic resilience [24].

Regarding domestic food security, the national perspective is optimistic, however there is increasing awareness of regional and socio-economic differences in access to food. Nationally, in 2020, the Australian Bureau of Agricultural and Resource Economics and Sciences (ABARES) concluded that with $70 \%$ of agricultural produce exported, Australia has one of the world's most secure food supplies, with substantial stocks of produce to guide the nation through the coronavirus pandemic [25]. However, the Australian Government's Inquiry into Intergenerational Welfare Dependence acknowledges that entrenched disadvantage is embedded in particular Australian communities, and is persistent and multi-causal [26]. This includes factors such as: geographic location; Indigenous and single-parental status; employment and education barriers; health and family welfare; and access to tailored support systems. Currently, the Australian Government identifies that the most vulnerable groups that experience insecurities for accessing and utilizing food include: Indigenous people; unemployed people; single-parent households; low-income earners; rental households; and young people. Additional groups who are described as susceptible to food insecurity can include: culturally and linguistically diverse (CALD) groups including refugees; people who do not have access to private or public transport; people who misuse alcohol and tobacco; and people who are disabled, unwell or frail [27].

Within Australia, the north-eastern Cairns region ('Cairns') is a compelling Australian case study to learn from in terms of its exposure, not only to weather extremes, but also to the prevalence of entrenched and intergenerational food disadvantage. Cairns is situated in the Tropical zone, which is prone to cyclones, storm surges, flooding and extreme heatwaves. Cairns relies upon food to be transported thousands of kilometers from the southern food-producing states. As such, the food-based contingency plans of citizens are reliant upon their own stockpiled, non-perishable food [28].

Systemic and chronic food disadvantage in the Cairns region include citizens that experience homelessness, ageing, disabilities, Indigeneity, multiculturalism, disengaged youth and those with multiple complex needs [28]. Geographically, Australians living in regional and remote areas such as Cairns are 33\% more likely to experience food insecurity than those living in cities. In 2019, the number of individuals seeking food assistance from charities that work with Foodbank Australia increased by $22 \%$, with only $37 \%$ of those charities assessing that they met the full needs of those they assisted. Children represented $22 \%$ of food-insecure Australians [14]. In the case of citizens who experience entrenched food disadvantage, food charities are central to meeting everyday food needs, but that food is also largely non-perishable, canned, bottled or tinned food. Reliance on food that has a long shelf-life with a typically poorer nutritional quality than fresh fruit and vegetables shows a policy failure to meet the needs of communities' vulnerable members that already experience health inequalities [29]. The systemic use of food aid is an indication of a stressed food system [30].

Cairns is a major global tourist destination and is the international gateway to the Daintree Rainforest and the Great Barrier Reef. With a high workforce reliance on international and domestic tourism, including airport travel, hotel occupancy and service industries, Cairns was the second most severely impacted economy in Australia due to COVID-19 [31]. The Australian government-funded 'JobKeeper' wage subsidy was estimated to keep 2.2 million Australians out of poverty [32,33]. Cairns was estimated to have the higher number of 'JobKeeper' wage subsidy recipients Australia-wide, with 90\% of businesses reporting negative effects from the economic lockdowns [31].

With the onset of COVID-19 in Australia in 2020, food-related disadvantage has intensified the experience of chronic, persistent food insecurity. It has also introduced many additional Australians to transitory food insecurity through sudden spikes in food shortages related to panic buying. In 2020, the Australian Foodbank Hunger Report 2020 identified two emergent groups experiencing food insecurity for the first time, including 
international students (who had no access to government financial support) and those in the casual workforce [14]. For Cairns, the exacerbated socio-economic stressors (disruptions) saw people, for the first time, unable to pay rent, and thus requiring access to government subsidy payments, charitable food aid and emergency financial relief. Many used mental health services for the first time [34].

As a United Nations Disaster Risk Reduction (UNDRR) Role Model City, Cairn Regional Council has participated in 'Making Cities Sustainable and Resilient' action planning $[35,36]$, which included demonstrated action in the area of 'disaster risk reduction' (DRR) to promote resilient and sustainable development [37]. Cairns was one of 20 pilot cities showcased for their planning progress to ensure the sustainability of their disaster resilience-building activities. In terms of leadership, Cairns benefits from having full-time focal points for disaster risk reduction. A local Disaster Coordinator and Resilience Officer support the coordination of core agencies, administrative departments and other key stakeholders. Furthermore, existing community awareness campaigns such as 'Be Ready Cairns' have encouraged community-level preparedness planning [35], including its existing 'Be Ready, Cairns! 2019-2024: 5-Year Resilience Strategy' (referred to as the Disaster Resilience Strategy herein). The local authority's strategic vision states that "Disaster resilience in the Cairns region is a collective responsibility, shared by all sectors of society. Community vulnerabilities are understood and incorporated in risk reduction measures. Our communities are ready for and able to recover effectively from disaster events" [37] (p. 6).

\section{Methods}

This study was conducted by Griffith University researchers in collaboration with the Cairns Regional Council's Disaster Management Unit, with the aim of building greater capacities for accessing short food supply chains. Given the lack of precedent in Australia, we adopted an evidence-based approach to investigating end-user needs and opportunities for embedding local food action within the local authority's disaster management agenda [28]. The research methods comprised literature review, and workshops and a survey for stakeholders (Griffith University approved ethics reference number: 2020/580).

\subsection{Literature Review}

A desktop review included document searches of peer-reviewed literature, government and non-government agency policies, and plans as they relate to the key conceptual themes for building local food resilience and contingency plans in the geographical locations of Australia, Queensland, and the case study region of Cairns. This included a detailed review of local food resilience and contingency measures within the Disaster Resilience Strategy. We sought to clarify avenues to support the region's most vulnerable community members, with a view to empowering the broader community at large to participate in their own resilience in the longer term.

Following the workshops and survey, an extant literature review was undertaken to contextualize the study within the existing literature about strategic priorities for planning ahead in an Australian and local (Cairns regional) context. This literature is referred to in the discussion, where Council's strategic priorities are discussed in relation to potential local food access actions.

\subsection{Case Study Set Up}

Three areas within the Cairns local government region were selected for the survey and interviews, to enable consideration of a broad range of vulnerable groups, as shown in Figure 1. 


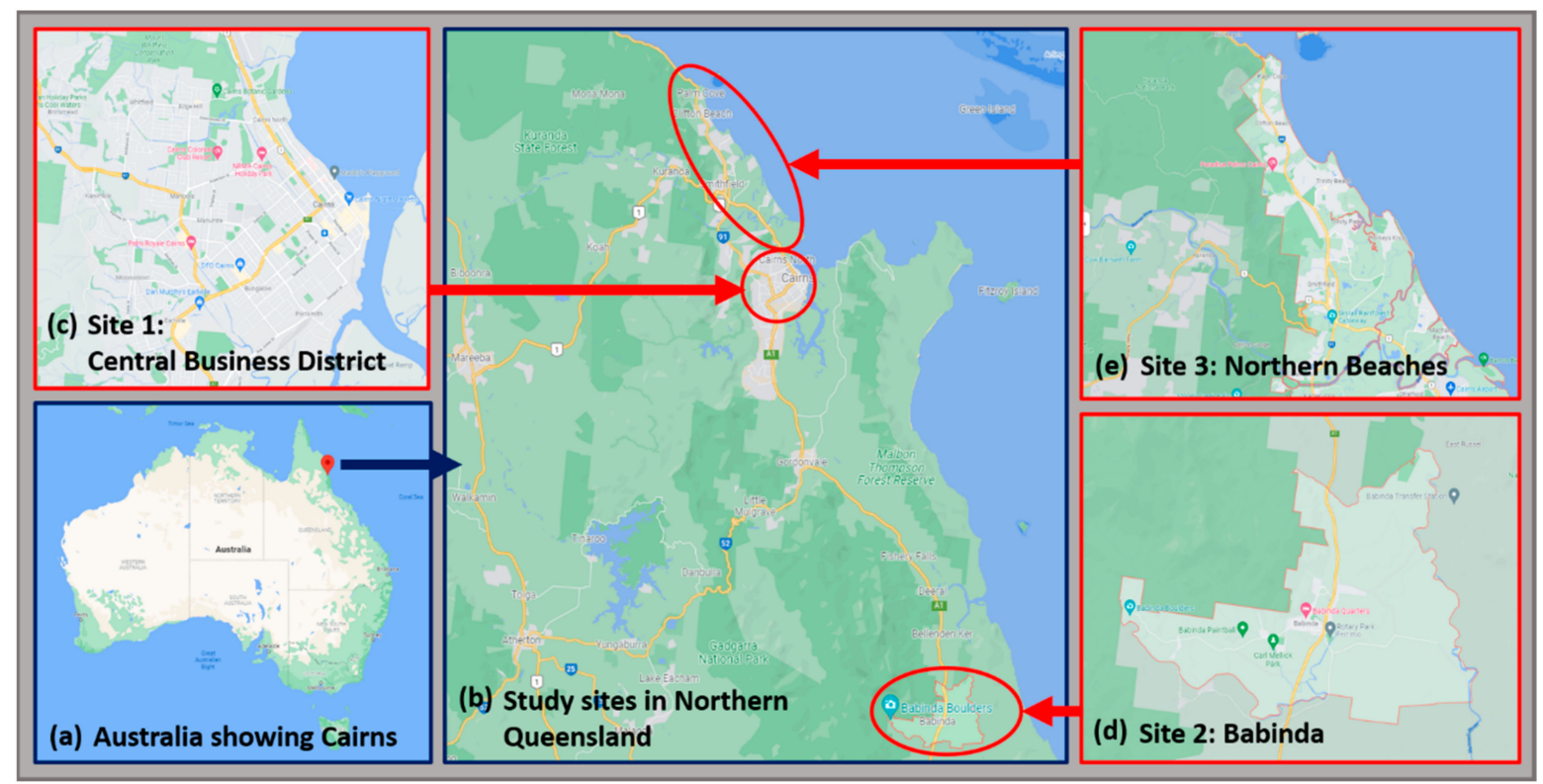

Figure 1. Study area locations in Cairns, Australia, comprising: (a) location of Cairns in Australia; (b) Cairns region indicating the three study area locations; (c) location 1: Central business district; (d) location 2: Babinda township; (e) location 3: Northern Beaches. Source: Created using [38].

The first area of study comprised those suburbs close to the central business district, in particular, the inner-lying suburbs of Bungalow and Portsmith (inner southern suburbs) and Manoora and Manunda (inner western suburbs). According to the last Socio-Economic Indexes for Areas (SEIFA) generated in 2016, only $6 \%$ of Australian townships are subject to worse socio-economic conditions than the suburbs of Bungalow and Portsmith. Furthermore, for the suburb of Manunda, it was 4\%, and for the suburb of Manoora, it was 3\% [39]. The characteristics include a high proportion of single-person dwellings, a large percentage of Aboriginal and Torres Strait Islanders, and the highest percentage of disengaged youth.

The second area of study comprised a small community located $60 \mathrm{~km}$ south from the Cairns Central district known as Babinda. Situated along the Bruce Highway, Babinda is only $7.4 \mathrm{~km}$ south of the Bellenden Ker township, which has the highest annual rainfall recorded in Australia [40]. The SEIFA data reveal that only $28 \%$ of Australian townships are subject to worse socio-economic conditions than the township of Babinda located in the rural south region of the Cairns district [39]. Characteristics of the Babinda township include a large, ageing community who are geographically distanced from health and community services.

The third study area comprised the Northern Beaches communities stretching for $26 \mathrm{~km}$ along the coastline, north of the Cairns Airport and the Barron River. SEIFA data show that the Northern Beaches are socio-economically better off than the other study sites but still sit within the Cairns regional profile, which is identified as less socio-economically privileged than the rest of the nation [41]. Characteristics include a high proportion of elderly people and families with young children.

\subsection{Stakeholder Workshops}

Two stakeholder workshops formed part of the study, to elicit local knowledge that might not be available in publications or online. Due to COVID-19 restrictions, both were conducted online via Teams, with discussions led by the lead researcher and the Cairns Regional Council, Disaster Management Unit. Participants were invited using an intentional snowball sampling method, comprising members within the Cairns Regional Council working across disaster management and social, economic and environmental sustainability.

Workshop 1 was held in May 2020, seeking stakeholder reflections about the importance of making locally accessed food part of everyone's lives. A total of 8 participants 
from 11 invitees attended. A thematic analysis of the key findings from the primary data collection involved sorting the findings into key themes and comparing them with opportunities and challenges identified in the literature. The findings were presented in Workshop 2 (online, December 2020), which provided an overview of the project progress and sorted participants' insights for integrating new information about local food resilience and contingencies within the five (5) pre-existing strategic priorities (Issue Groups) of the Disaster Resilience Strategy. Again, 8 participants from 11 invitees attended. The workshop discussions were compiled into a briefing note under each priority for council participants to refine and add further suggestions.

\subsection{Stakeholder Survey (Online and Telephone Interviews)}

The research team conducted a survey using an online tool ('Stage 1 survey data collection') and telephone interviews ('Stage 2 survey data collection') with individuals employed by non-government organizations working on behalf of the most vulnerable members in the Cairns region (For details of the questions, see Appendix A: "Accessing Local Food in Cairns"-Online Survey and Telephone Interview Questions). It was assumed for this study that the organizations would be able to discern trends about their clientele appreciation of information about food access and actual experiences of food access. This enabled the survey questions to extend beyond the organization, to explore clientele appreciation and lived experiences of food insecurity without contacting community members directly, many of whom were living with existing stressors exacerbated by the first-wave onset of COVID-19.

The survey questions were created from a review of policy-based and peer-reviewed literature, and ordered and refined using the findings from the workshop exploration of the topic area with Council employees (key literature from this search has been cited within this paper where relevant). These five areas comprised: (1) knowledge versus practice of food emergency preparedness; (2) the awareness of, compared to the use of, local food options; (3) imagining the need for food support and services based on future food-shortage scenarios; (4) the likelihood of accessing local food options in the future; and (5) actions to support access to local food options. Questions were subsequently developed for each theme and questions comprised of a mixture of: (a) closed questions with boxes to check from pre-determined responses and a Likert Scale to indicate the likelihood of given responses; and (b) open-ended questions based on imagining outcomes based on two (2) scenarios. The survey was scaled to be completed within $10 \mathrm{~min}$.

A total of 47 organizations were selected from an online search with input from the Cairns Regional Council, Disaster Management Unit who have contact and work in close connection with such groups. The organizations were selected to invite participation in the survey if they worked with members of the community who experienced existing socioeconomic vulnerabilities that are exacerbated during times of natural disaster, with more challenged access to basic resources and prolonged recovery needs. Of the 47 organizations contacted, 22 responded through: Stage (1), involving online data collection (13 responses); and Stage (2), involving direct contact with remaining invitees to undertake telephone interviews (8 responses) to boost the response rate, further to receiving revised ethical clearance. The same survey questions were verbally posed to participants with their responses typed into a word document. The survey results were compiled on an Excel spreadsheet and analyzed to map the trends in survey responses.

\subsection{Limitations in the Study}

Due to the first onset of COVID-19 in 2020, a two-month delay to the initial timeline of the study occurred due to Australia-wide job losses and large-scale organizational restructuring both within the University sector and the local authority. Travel restrictions and requirements for physical distancing necessitated that all interactions for the workshops and surveys be conducted online or by telephone. The survey and telephone interview data may have been more expansive if data could have been collected in person via 
interviews. Similarly, if the workshops were conducted via in-person focus groups, the opportunities for casual and incidental comments would have provided additional insights. Notwithstanding these limitations, the data integrity was considered sufficient to proceed with analysis.

\section{Results}

In the following paragraphs we describe the characteristics of the participants and who they represent, then present the findings from the workshops and the survey. Outlining the study findings will facilitate the forthcoming discussion on improved end-user needs appreciation for vulnerable community members, and how access to local food can make a difference to overall disaster management arrangements.

\subsection{Participant Characteristics-Workshops and Survey}

The two workshops with council staff were conducted online via Teams due to COVID-19 physical restrictions, to determine the values and priorities of the council in building a local food resilience and contingency hub. As the council identified the need for an all-hazards approach to disasters, a range of council staff across various portfolios were invited to attend including disaster management, sustainability (energy, water and waste), business operations and community development. These attendees were also representatives for selecting the right groups to engage with for addressing the problem.

An online search was undertaken to determine the core business of the 47 organizations invited to participate in the study survey. The search revealed a primary focus on assistance for the homeless, including short-term crisis intervention, emergency accommodation and those at risk of homelessness, as shown in Figure 2.

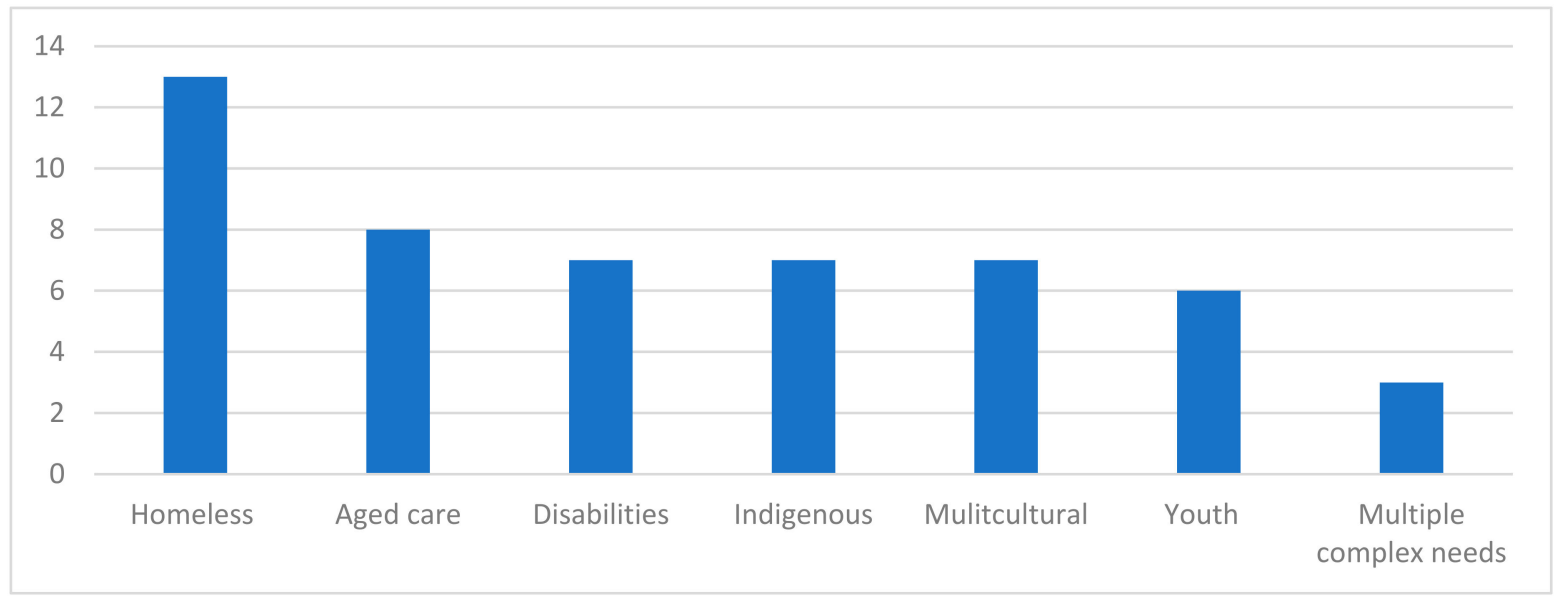

Figure 2. Summary of aid organizations working in Cairns, by vulnerable group type (some organizations deal with more than one group type).

\subsection{Workshop Findings}

\subsubsection{Workshop 1 'Scoping Session'}

The first workshop was conducted in May 2020 to determine the key opportunities, challenges and potential actions to start a local food resilience and contingency project. The workshop revealed the importance of making locally accessed food part of people's everyday lives. In spite of the local food activities with the advent of severe weather events and pandemics, the council recognizes that there are no formalized arrangements for coordinated food action, leading to local leaders experiencing repeated knowledge loss following events, with coordination reliant on a small number of council staff and volunteers. Through a mapping exercise, six key priorities emerged that participants agreed were important to guide further investigation: 
1. Local food access support: Improve the availability of platforms for accessing local food;

2. Awareness: Emphasize a holistic appreciation of local food resilience in Cairns;

3. Innovation support: Enable an online platform of local food resilience innovations;

4. Dashboard use: Utilize the existing Cairns Disaster Dashboard for local food contingency;

5. Communication: Communicate desired behavior changes; and

6. Food bowl mapping: Map the local food options within the region's food bowl.

These priorities were subsequently circulated within Council leadership to discuss internal support for and interest in proceeding with these items.

\subsubsection{Workshop 2 'Key Insights Session'}

The second workshop was conducted in December 2020 to deliberate how those actions could be integrated within the strategic priorities of Cairns' Disaster Resilience Strategy. The session revealed insights for integrating local food access within disaster management resilience and contingencies. The resulting local food access priorities for Cairns were mapped to the five 'Issue Groups' already identified by the council within its Disaster Resilience Strategy. This mapping is summarized in Table 1.

Table 1. Food local access enablement mapping to disaster management priorities.

\begin{tabular}{|c|c|c|c|c|c|c|c|}
\hline \multirow{2}{*}{\multicolumn{2}{|c|}{$\begin{array}{c}\text { Disaster Management Strategic } \\
\text { Priority [37] }\end{array}$}} & \multicolumn{6}{|c|}{$\begin{array}{l}\text { Mapped Local Food Access Priorities for Cairns } \\
\text { (Workshop } 1 \text { Priority Action Areas) }\end{array}$} \\
\hline & & 1 & 2 & 3 & 4 & 5 & 6 \\
\hline 1. & $\begin{array}{l}\text { Maintain and grow year-round } \\
\text { all-hazards understanding } \\
\text { and preparedness }\end{array}$ & $\checkmark$ & & & $\checkmark$ & & $\checkmark$ \\
\hline 2. & Fill resilience knowledge gaps & $\checkmark$ & $\checkmark$ & $\checkmark$ & & & $\checkmark$ \\
\hline 3. & $\begin{array}{l}\text { Build internal and external } \\
\text { adaptive capacity and capability }\end{array}$ & $\checkmark$ & $\checkmark$ & $\checkmark$ & & & \\
\hline 4. & $\begin{array}{l}\text { Build active community } \\
\text { engagement in } \\
\text { resilience building }\end{array}$ & & & $\checkmark$ & & $\checkmark$ & \\
\hline 5. & $\begin{array}{l}\text { Focus on communities needing } \\
\text { the most support }\end{array}$ & & $\checkmark$ & & & $\checkmark$ & \\
\hline
\end{tabular}

Participants agreed that in light of the growing socio-economic trends and the general lack of preparedness, the development of an online 'Local Food Resilience Hub' on council webpages would be prudent and practical for growing an ongoing and 'all-hazards' preparedness based on locally accessed food for the region's most vulnerable citizens. In terms of additional food support that should be available to the clientele of their organization during multiple disaster conditions, one respondent from the survey stated, the need for "online tools, apps and resources to help develop a planned response".

\subsection{Survey Findings}

Discussions from Workshop 1 were useful in determining a list of five themes of interest to the council to inform actions. They comprised: (1) knowledge versus practice of food emergency preparedness; (2) awareness of, compared to use of, local food options; (3) imagining the need for food support and services based on future food-shortage scenarios; (4) the likelihood of accessing local food options in the future; and (5) actions 
to support access to local food options. The resultant five themes generated from the workshop discussions are outlined as follows.

\subsubsection{Knowledge Verses Practice of Food Emergency Preparedness}

There is a high degree of knowledge about how to access emergency food supplies, with organizations playing a significant role in accessing those supplies on behalf of their clientele, as shown in Figure 3.

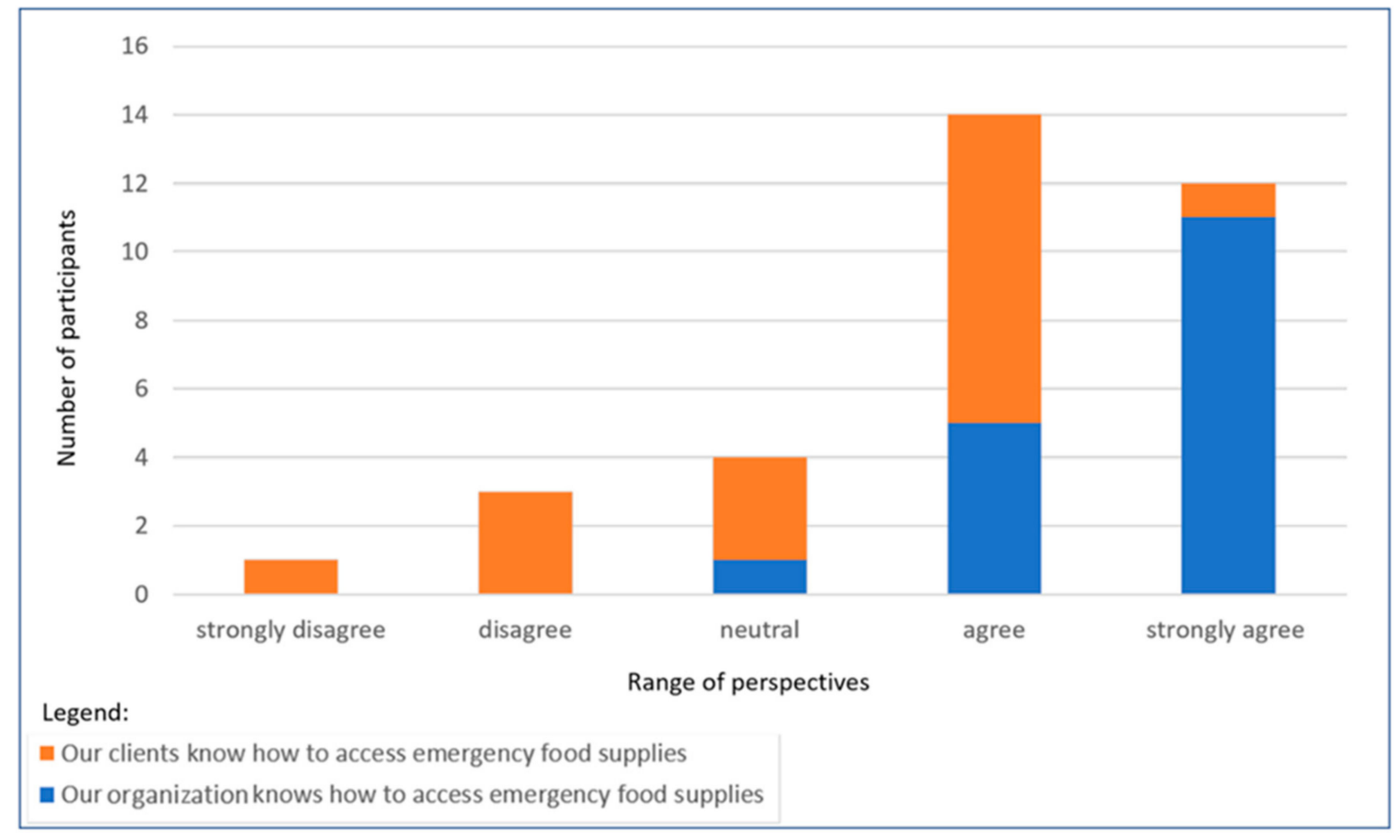

Figure 3. Knowledge of how to access emergency food supplies.

The results show a strong lack of practical actions undertaken to ensure the minimum 3-day emergency supply of food. Comparing Figure 3 with Figure 4 below, a pronounced gap can be seen between the prevalent knowledge of how to access emergency food supplies of both organizations and their clientele, in contrast to the lack of actually practicing the minimum 3-day supply of emergency food.

\subsubsection{Awareness of and Use of Local Food Options}

Considering awareness of a range of local food access options compared with the actual use of those options, respondents provided a range of options for the categories provided. Figure 5 highlights the higher levels of awareness of all the listed options, compared with the reported use of these options during previous disaster events.

The most common responses of actual use included food markets, followed closely by emergency supply, food aid and volunteer organizations, and then direct delivery of fresh produce. In equal measure, this was followed by direct purchasing from farmers, drawing upon home-grown gardening efforts and accessing bulk supplies from wholesale food outlets. Finally, a small number of community gardens were accessed with no access to food sharing initiatives, even though there is a reported awareness of food sharing as an option. 


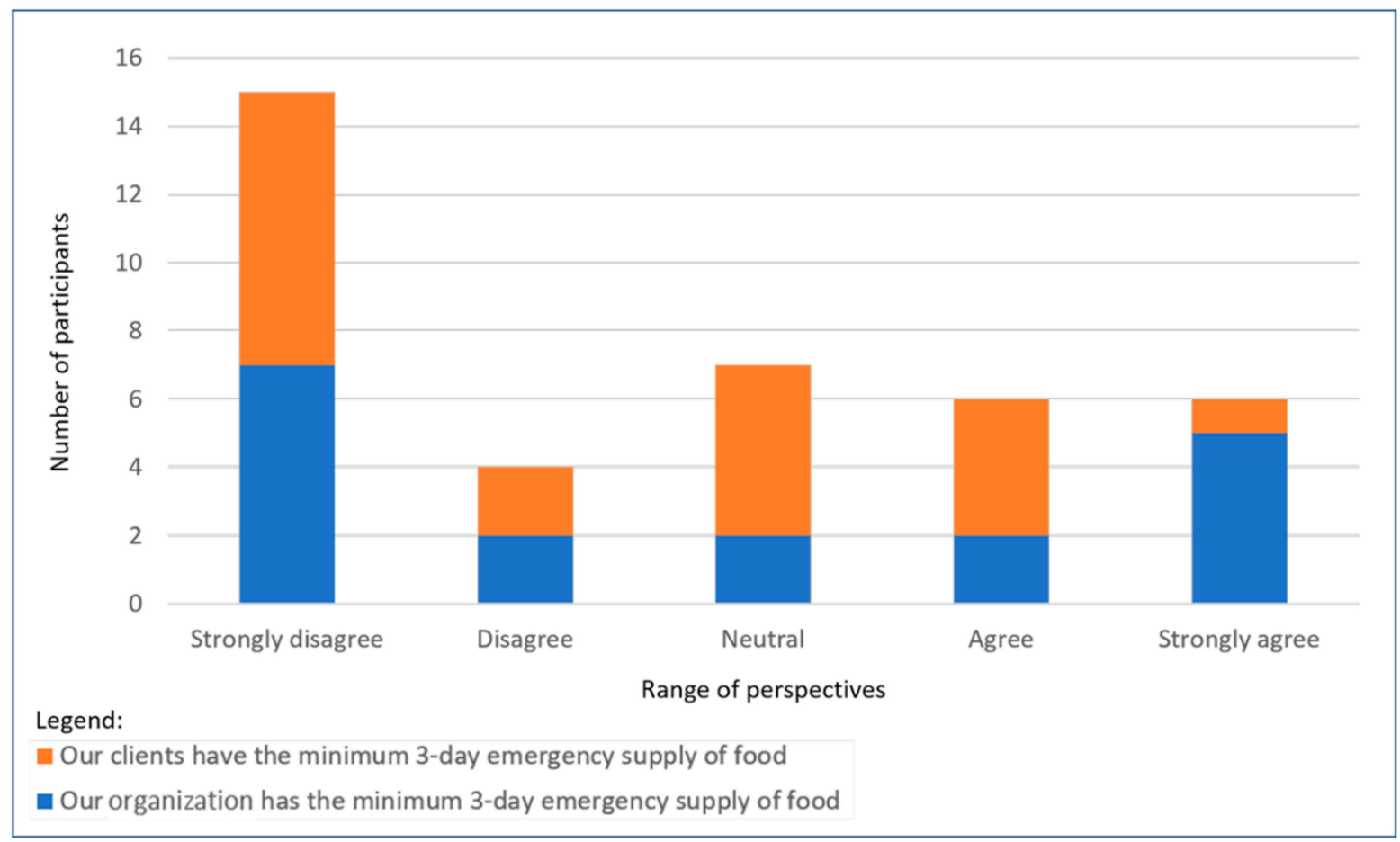

Figure 4. Practicing the minimum 3-day emergency supply of food.

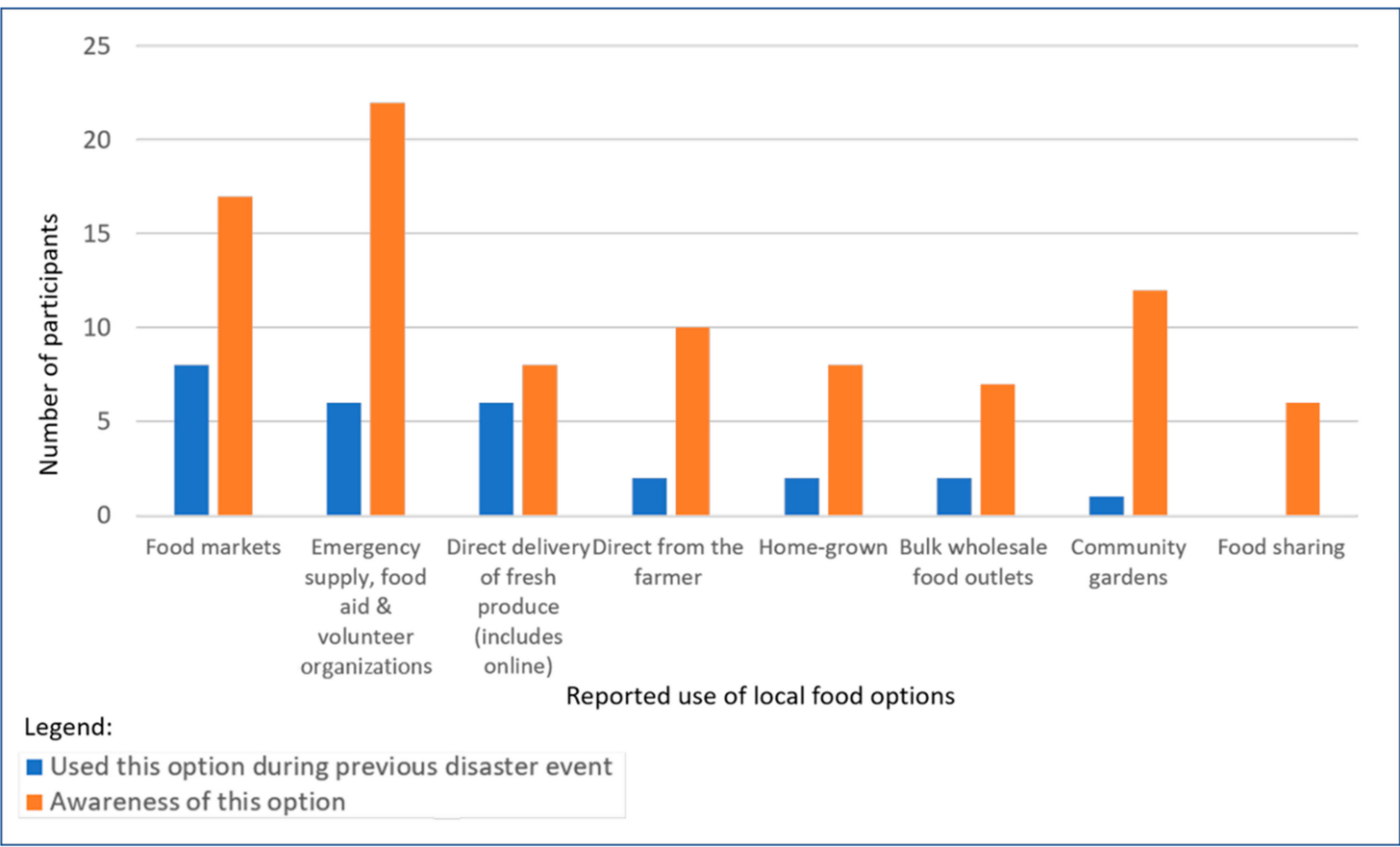

Figure 5. Awareness of local food options compared to reported use of those options during a previous disaster event.

\subsubsection{Food Support and Services Based on Future Food-Shortage Scenarios}

Respondents were asked to imagine two scenarios and provide open-ended comments about the additional food support and services they thought would be beneficial to deal with each scenario. The qualitative responses were collated, and revealed the need for a more formalized and anticipatory set of actions for times of hardship. Each scenario is 
outlined below with key themes summarized. Selected quotes are employed throughout the discussion section.

As the data collection was conducted during the COVID-19 conditions spanning June to September 2020, the first scenario involved the anticipation of a second wave as outlined with Scenario 1 and the following Question: "There is a second wave of COVID-19 in the Cairns Region. This has resulted in limited access to food, more calls for social distancing and added measures to reduce the spread. What additional food support and services should be available to your organization?" The qualitative responses included:

- $\quad$ Ensuring continuity of online ordering and delivery avenues;

- Delivering online and via food charities;

- $\quad$ Ensuring the flow of fresh fruit and vegetables;

- Accessing supermarkets outside of business hours;

- $\quad$ Building capacities to bulk order with bulk deliveries;

- Maintaining food stockpiles;

- Facilitating the connection between food sources and community members;

- Accessing information on affordable food sources and delivery options;

- Minimizing panic buying; and

- Centralizing coordination to reduce the duplication of efforts.

The second scenario asked respondents to imagine compounded disaster conditions as outlined with Scenario 2, and the Question: "The Cairns Region is experiencing a cyclone and pandemic at the same time. This has resulted in limited access to food and damage to buildings including houses and shopping centers. What additional food support and services should be available to the clientele that your organization supports?" The qualitative responses included:

- Accessing networks engaged with emergency food supplies and food parcels;

- Connecting with online tools, apps and resources to help develop a planned response;

- Coordinating the emergency response to reduce duplication of efforts;

- Using kitchen facilities to mass produce food;

- Utilizing mobile catering units and vans;

- More planned and structured times for food shopping;

- Earlier interventions to reduce hoarding;

- Maintaining food stockpiles and bottled water;

- Accessing food via food delivery and servicing large numbers of people;

- Information about affordable food sources and delivery services;

- Information about community gardens;

- Emergency relief support;

- $\quad$ Getting the business district active as soon as possible; and

- Accessing more food information and action, including food handling and hygiene support.

Participants were given the option of offering additional insights and comments. The question was posed: "Are there any more ideas that have not been covered that you would like to comment on?" The qualitative responses included:

- Supporting Buy Local campaigns;

- Accessing affordable fresh food;

- Allocating suitable land parcels to those who wish to grow food;

- Better procurement lines for food to inform contingency arrangements;

- Anticipating the needs of people who do not know how to get help or ask for help;

- Longer-term focus on sustainable solutions, capacity building, and resilience;

- Not just relying on the internet and mobile phones for communications and continuing messages about maintaining stockpiles;

- A reliance on emergency food aid is due to limited planning;

- Authoritative measures around food safety can be a hinderance; and

- Improved coordination and shared responses that also help to create options. 


\subsubsection{Accessing Local Food Options in the Future}

Utilizing a Likert Scale, respondents were asked to indicate how likely they would be to use the following food options in future events? A score of $0=$ never and $4=$ highly likely. Using the 17 responses to this question, the likelihood scores for each option from the responses were added to gain a cumulative score. Figure 6 shows that accessing food markets and emergency supply outlets remain the most likely courses of action, followed by bulk wholesale and direct purchasing from the farmer. The figure also shows that food sharing is a likely option for future disaster events.

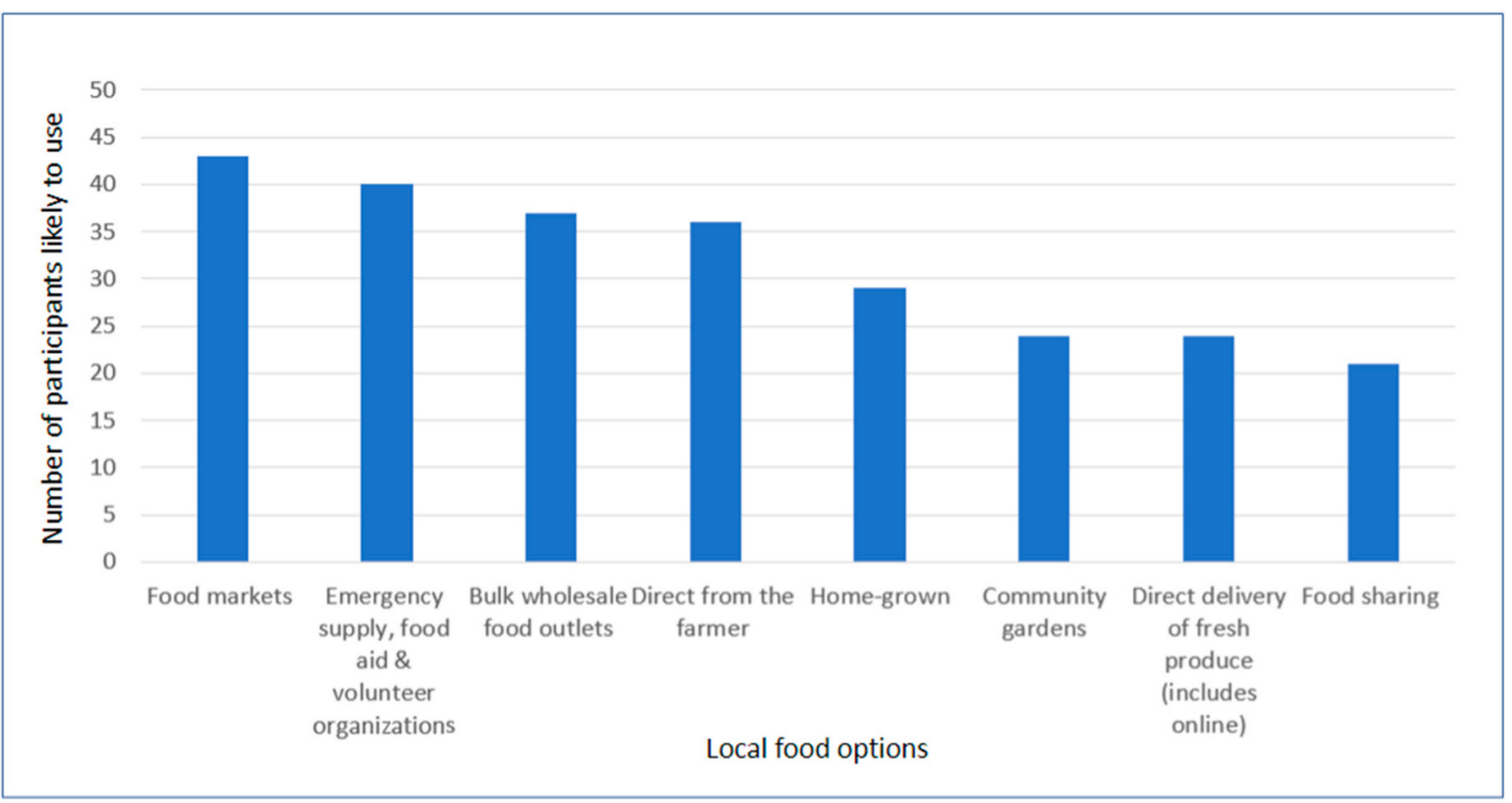

Figure 6. Likelihood of using local food options in future events.

\subsubsection{Supporting Access to Local Food Options}

The first line of questioning focused on capturing the knowledge of organizations and their clientele for accessing disaster event information from the Cairns Regional Council, as an indication of their awareness for accessing the most appropriate information. Utilizing a Likert Scale, respondents were asked to indicate how they would rate statements for the organization they work in and their perception of how their clients might rate the same question.

The results of the Figure 7 show that organizations and their clients have strong knowledge about accessing information. The organizations are overall more knowledgeable on how to access disaster event information, and may therefore, be good advocates for their clients in accessing the best information.

The next line of questioning focused on the kinds of content and information that organizations might find useful from the council to support their access to local food options. The respondents were presented with the action options listed in Figure 8 and were asked to 'tick' as many options from the list that apply to this question: "How can the Cairns Regional Council support your organization's access to local food?" 


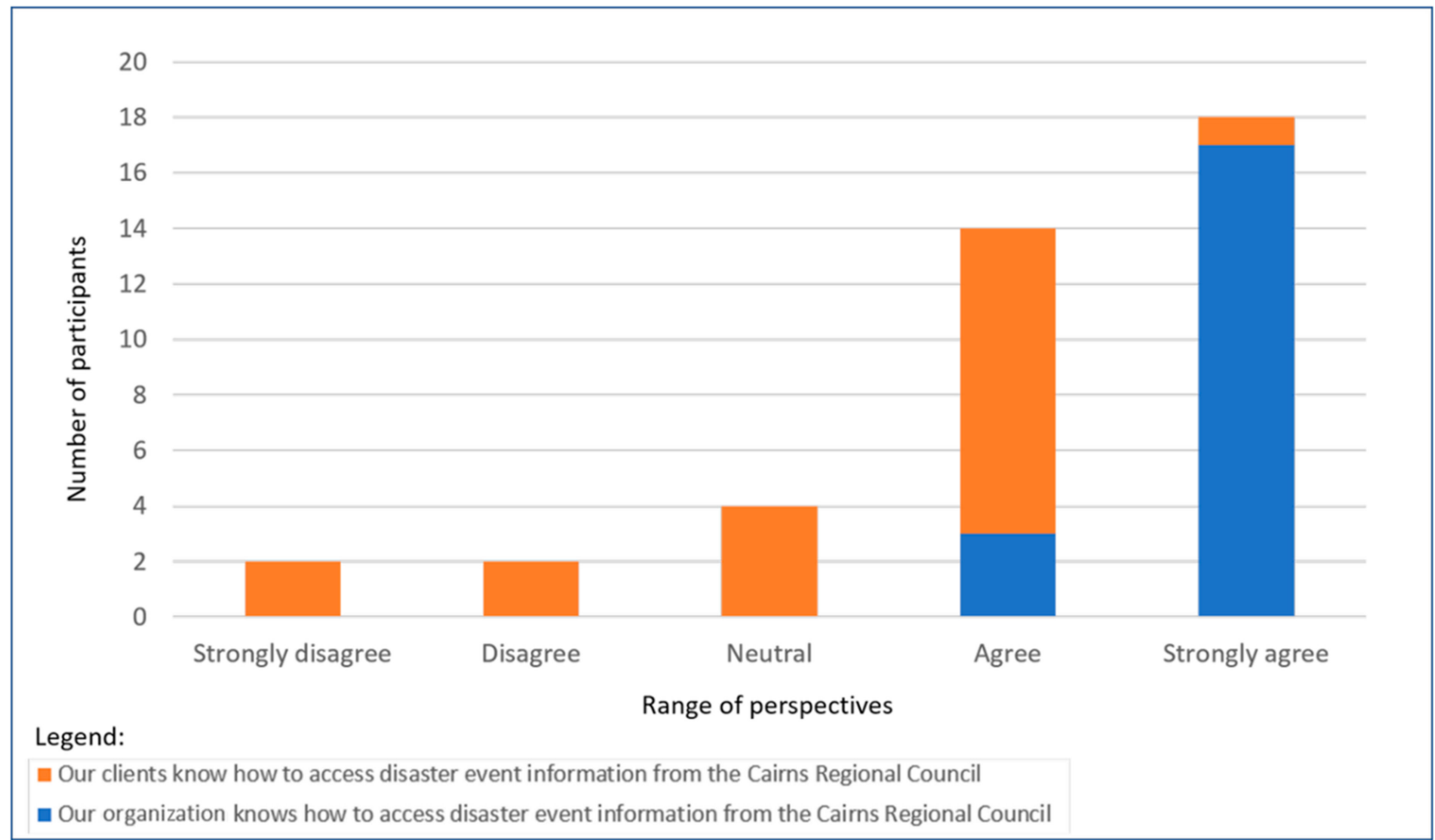

Figure 7. Organizations and clientele know how to access disaster event information from the Cairns Regional Council.

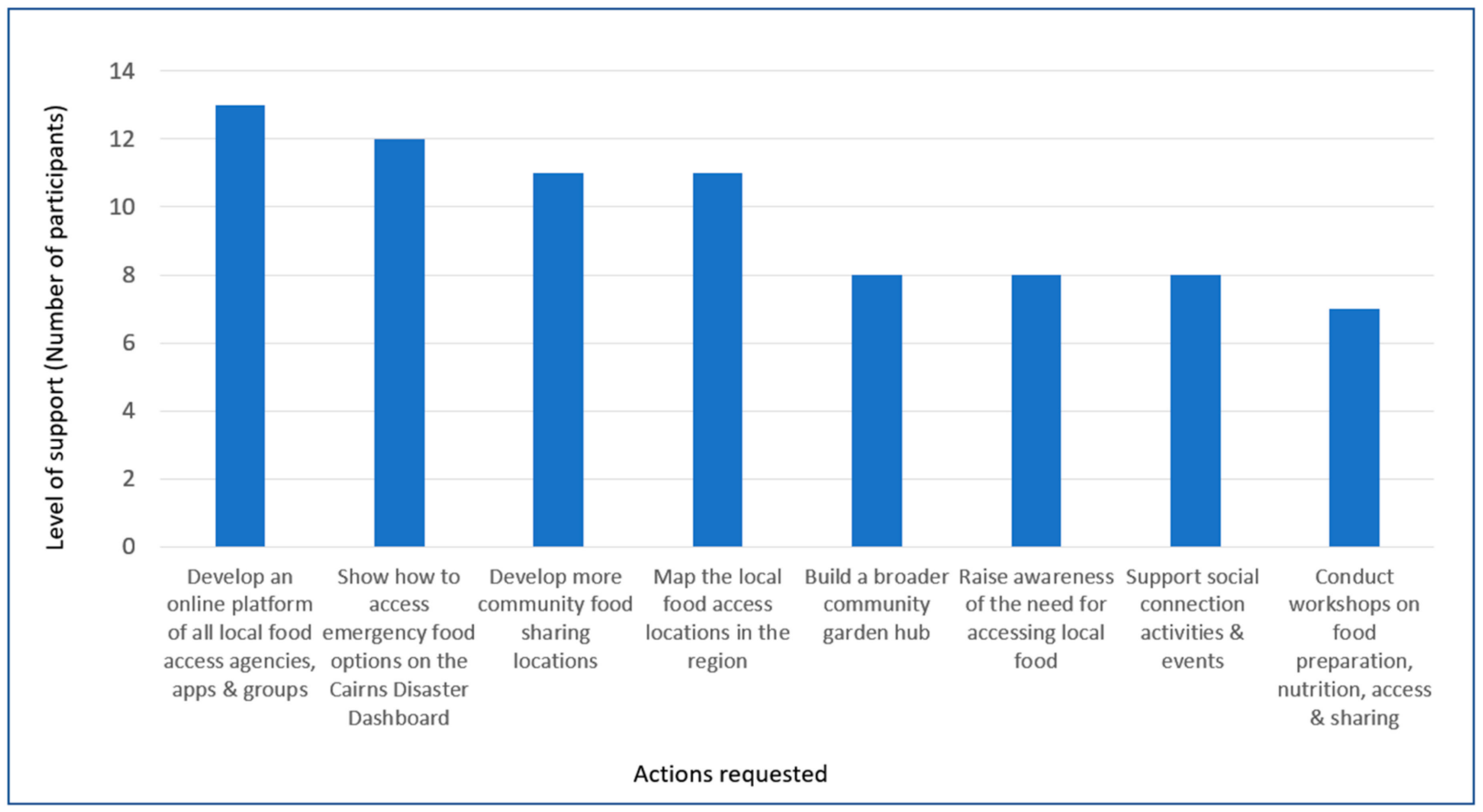

Figure 8. Supportive actions requested of Cairns Regional Council.

The results show that the development of an online platform of all local food access agencies, applications and groups is most needed, followed closely by utilizing the existing Disaster Dashboard to show how to access food options as emergency supplies. The next two most important actions include developing more community-food-sharing locations and mapping the local food locations within the Cairns region. 


\section{Discussion}

In the following section we discuss the study findings regarding improved end-user needs appreciation for vulnerable community members, and how access to local food can make a difference to overall disaster management arrangements. We then consider the implications of these findings for other local authorities in Australia and elsewhere regarding the potential for local food access arrangements to be embedded within the disaster management processes (PPRR), to support vulnerable populations.

\subsection{Connecting Local Food Access with Disaster Management for Resilience Priorities}

Mapping the local authority's strategic priorities with practical enablement opportunities that were raised during the workshop and canvassed during the survey, we created a Local Food Access Model towards achieving key disaster management for resilience outcomes, as presented in Figure 9.

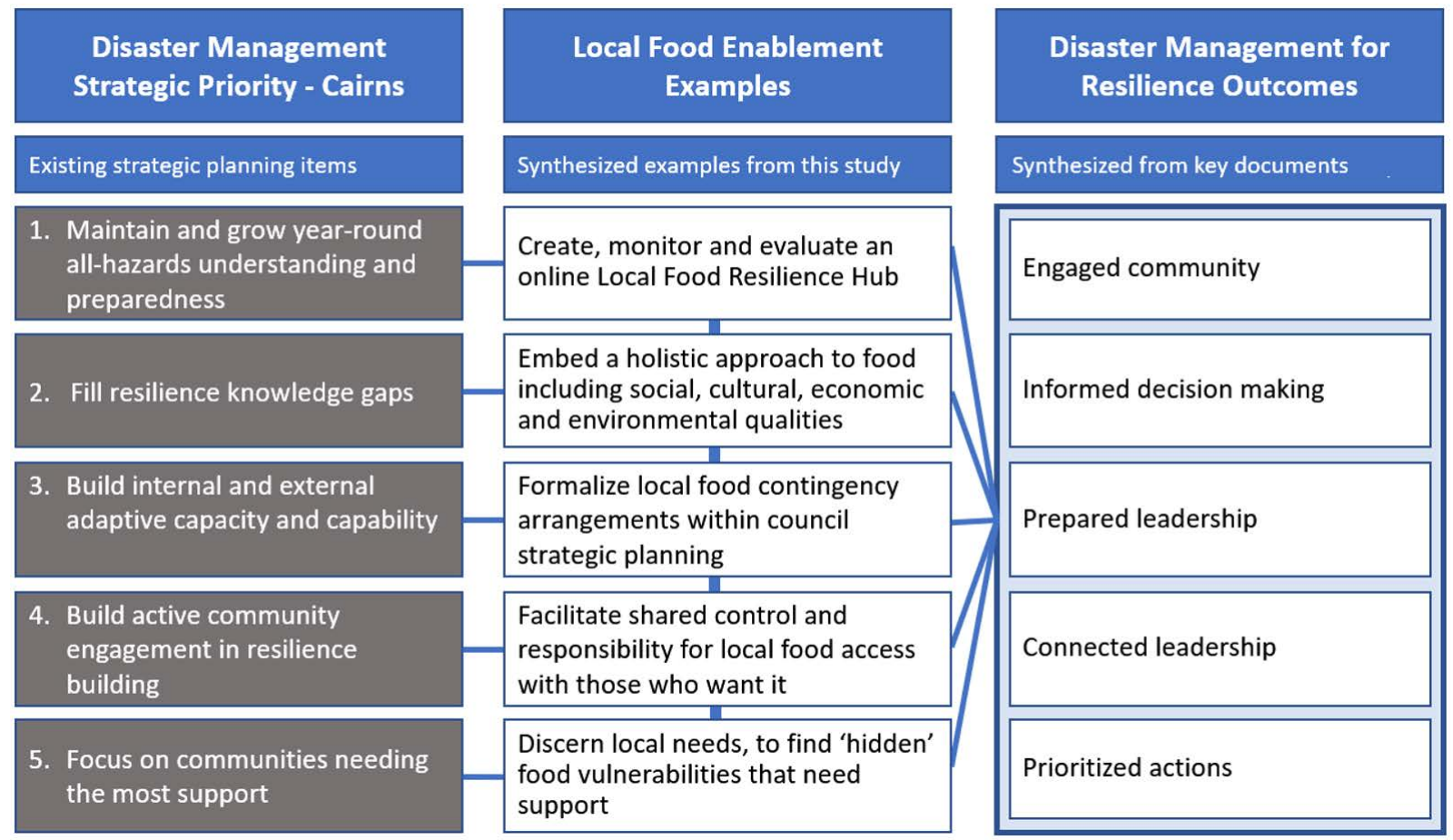

Figure 9. Local Food Access Model for decision support, applied to Cairns Regional Council. Source: Orignal Figure integrating priorities from sources $[16,17,37]$.

The first column of Figure 9 shows the five pre-existing strategic priorities of the Cairns Disaster Resilience Strategy [37]. The second column highlights examples of local food enablement associated with the respective priorities that emerged from our study. The third column indicates aspirational targets identified within the field of disaster management $[16,17]$ that, in conjunction with contextual insights from columns one and two, can build decision support for local food resilience. The local food access enablement items from column two of the model are discussed in the following paragraphs, to address the council's five strategic priorities. For each priority we reference key literature, workshop discussions and survey findings. The following paragraphs describe each of the strategic priorities (i.e., Column 1 of Figure 9), regarding examples from our Cairns-based research (i.e., Column 2 of Figure 9), so that practitioners may consider future opportunities in policy-making and planning to achieve the 'disaster management for resilience' outcomes listed in Column 3 of Figure 9. 


\subsubsection{Priority 1: Maintain and Grow Year-Round All-Hazards Understanding} and Preparedness

In the broader context of disaster management, the day-to-day use of a local food access platform or 'hub' would provide community members with a place to engage with local producers and suppliers. This also has the significant benefit of making interactions more visible for the monitoring of community understanding and preparedness for hazards. The findings of this study indicate that participants see the need for accessing local food options but do not necessarily know how to act upon them. Furthermore, there is a likelihood that expanding the range of options will be willingly received. This is encouraging given the need to address evolving trends in food insecurity

Following the COVID-19 pandemic outbreak in 2020, the Food Security Information Network (FSIN) and Global Network Against Food Crises released the '2020 Global Report on Food Crises' [42]. While Australia is not a part of the study, the report outlines trends affecting food security in developing and emerging economies. Considering this list below, we observe similar trends Australia-wide, with researchers McKay et al. [43] anticipating a continued reliance on food aid by welfare recipients given the current economic conditions in Australia, with the ongoing need to manage the COVID-19 pandemic. The trends include:

1. Economic recession: Border closures and the need for shutdowns and social distancing has far-reaching impacts led by systemic economic contraction [44-46].

2. Loss of income: Reductions in the opportunities for employment and steady incomes has increased reliance on government assistance for meeting basic living necessities [47-49].

3. Constrained government finances: The costs of managing the pandemic and supporting social and health systems is necessarily expensive [50,51].

4. Disruption to food systems: The emptying of supermarket shelves and spiked periods of panic buying requires revised and emergency capacities for restocking supermarket shelves. Due to border closures, disruptions also include the loss of migrant labor [52,53], essential for harvesting Australian crops [54]. This has added to a loss of supply of food items, and price increases [55].

5. Deepening inequalities: The loss of income from closures is deepening the inequalities experienced by those who are already subject to poverty conditions [56-58]. Increasingly, more people who are not 'normally' within the poverty bracket are experiencing those conditions, as reported by Foodbank Australia in 2020 [14]. In 2021, Foodbank Australia reported that one in every six Australian adults did not have enough to eat [59].

6. Increased pressure on food aid and food relief: With the loss of reliable income for many citizens, safety nets such as charity outlets experience increased pressure to provide everyday food relief [43,60-62].

7. Mental health: Cumulative effects have seen the rise of mental health concerns nationwide [63-66]. A joint Statement by the Australian Medical Association called for "an urgent need to prioritize mental health and suicide prevention" [67] (Para 3).

Due to pandemic conditions, in developed nations, there is an evident movement toward accessing local and regional food supplies (for example, [6-9]). Findings from the survey (Figures 3 and 4) show a discrepancy for the Cairns region between what people 'know' and 'do' with regard to accessing local food options. The results showed a strong lack of practical actions undertaken to ensure the minimum 3-day emergency supply of food. There is a pronounced gap between the prevalent knowledge of how to access emergency food supplies in both organizations and their clientele, in contrast to the lack of actually practicing the minimum 3-day supply of emergency food. In terms of additional food support that should be available to the clientele of their organization during multiple disaster conditions, one respondent from the survey stated, the need for "access networks engaged with emergency food supplies". Another suggested "more centralized coordination to reduce duplication of efforts". 
The findings from the survey shown in Figure 6 demonstrate that the levels of awareness of all the listed local food access options is far greater than the reported use of these options during previous disaster events. In terms of the likelihood of accessing local food options in the future, the findings from Figure 6 show that accessing food markets and emergency supply outlets remains the most likely course of action, followed by bulk wholesale and direct purchasing from the farmer. While Figure 5 shows that there is no reported use of food sharing, Figure 6 reveals that food sharing is a likely option for food access in future events.

The findings indicate that participants see the need for accessing a range of local food options that are characteristic of shorter food supply chains (SFSCs) but do not necessarily know how to act upon them. SFSCs generally aim to reduce the number of actors that intercede a more direct relationship between the food producer, at one end of the spectrum, and the food consumer at the other end of the spectrum [68]. Furthermore, there is a likelihood that expanding the range of options will be willingly received.

\subsubsection{Priority 2: Fill Resilience Knowledge Gaps}

Activating SFSCs requires filling gaps in the knowledge of disaster resilience officers and policy practitioners about the more nuanced relationships people can have with food systems, and their capacities for enhancing food-based resiliencies. When people are brought "spatially, economically and socially closer to food" the relationships afforded by those proximities can support improved decision making for resilience [69] (p. 1).

In our study, one survey respondent suggested that "a longer-term focus on sustainable solutions, capacity building and resilience" is needed. In this way, we can be afforded the opportunity to view how others choose to reduce their food miles [70,71]. Similarly, people can participate in the experience of farmers of transitioning to farming methodologies with lower impacts on the surrounding environments [72]. To several respondents, building relationships with farmers was seen as beneficial as it, "facilitates connection between food sources and community members" and may "ensure flow of fresh fruit and vegetables". Furthermore, these relationships may build the "capacity to bulk order with bulk deliveries" and improve the "maintenance of food stockpiles".

Likewise, through SFSCs, we can experience how local and regional townships, their families, and local businesses are financially supported through social linkages [73]. One respondent stated that during and immediately after disaster events, their organization could be supported by "getting the business district active as soon as possible" while another said, "support Buy Local campaigns".

Another aspect of SFSCs is supporting equity of food access [74]. A number of respondents suggested that their organization could be better supported during a disaster with "access to information on affordable food sources and delivery options". Some creative solutions included the "use [of] kitchen facilities to mass produce food," and that we "utilize mobile catering units and vans". These kinds of initiatives are often associated with innovation through social enterprise [75], such as new collectives in short food chain supplies. As one respondent offered, the council could "allocate suitable land parcels to those who wish to grow food". For another respondent, it was suggested that the council's efforts should be focused upon creating options for accessing food locally.

\subsubsection{Priority 3: Build Internal and External Adaptive Capacity and Capability}

Building external adaptive capacity and capability refers to the public domain and the local partnerships and relationships outside the boundaries of the Cairns local government operations. In Figure 8, organizations in the care of vulnerable people identified that they are good advocates for their clients in accessing the best information about local food access options on their clients' behalf as their clients are often immersed in, and otherwise distracted by, difficult circumstances. Rather than relationships with food being shaped by distant and anonymous agents [76], local partnerships are more apt to share uncertainties around food, and therefore set up a form of insurance for those uncertainties [77]. This can 
be seen, for example, by the spike in online purchasing and direct delivery of food from farmers to buyers (see [78]), which, prior to COVID-19, was already known to strengthen local connections [79]. This knowledge is reflected in the council's efforts to enable an online platform of local food resilience innovations, including improving the availability of existing online platforms for accessing local food and emphasizing a holistic appreciation of local food resilience in Cairns, as discussed with the previous two strategic priorities.

Building internal adaptive capacity and capability refers to the organizational operations and departmental relationships within the Cairns local government. The United Nations Food and Agriculture Organization (UN-FAO) advocates that smaller-scale food access options play an important role in local governments and their capacity to respond to COVID-19 food emergencies [80]. Workshop 1, the Internal Scoping Session held with members of the Cairns Regional Council revealed importance of making locally accessed food part of people's everyday lives. Participating Council staff ranged across disaster risk management, community development and a range of sustainability-related portfolios, demonstrating the importance of transcending siloed boundaries and engaging in interagency communication and collaboration [81].

Formalizing local food contingency arrangements (back up plans) within the council's Disaster Resilience Strategy is a prudent and practical measure to anticipate time of food shortage [21]. This requires the explicit inclusion of accessing local food options within strategic planning as a Plan B or a Plan C, in case of interruption to the 'normal' supply [82]. One respondent from our study stated that, "limited planning has led to reliance on emergency food aid". Respondents in our study emphasized the need for "earlier interventions to reduce hoarding" and to "minimize panic buying". This further necessitated "food contingencies [that] require better procurement lines for food". In this way, it was asserted that a "coordinated emergency response [could] reduce duplication of efforts" and thus facilitate a "shared response".

\subsubsection{Priority 4: Build Active Community Engagement in Resilience Building}

Community engagement is core business in Australian disaster risk management and is defined by the Australian Institute for Disaster Resilience (AIDR) as "the process of communities and partners working together to build resilience through collaborative action, shared capacity building and development of strong relationships built on mutual trust and respect" [83] (p. 4). In our study, organizations were asked how Council can best support their clients' access to local food options. An online food resilience hub was identified as the most desirable type of content that would be useful from the council to support organizational access to local food options on behalf of clients. With pandemic conditions, there has been a global surge in online food shopping and delivery to meet the need for physical distancing [84].

Additional information of high importance, as shown in Figure 8, included: (a) developing more community-food-sharing locations that emerge to address socio-economic hardship and employment uncertainty; and (b) mapping the local food locations within the Cairns region (for example, [85]). As the online platform grows over time, and local food access becomes a more normalized part of everyday living, the existing Disaster Dashboard may then be considered as an avenue to access food options as emergency supplies. One respondent clarified that in the event of multiple disasters, such as a cyclone during infectious pandemic conditions, "access to food via food delivery and servicing large numbers of people" is vitally important.

For disaster resilience practitioners charged with community engagement, it is important to "gain a strong understanding of the unique history, values, diversity, dynamics, strengths, priorities and needs of each community" [83] (p. 10). Concerns about the ability of longer food supply chain models to withstand ongoing disruptions highlights the need to consider and act upon science-led evidence and socio-cultural values with the industrygovernment leadership of the agri-food sectors [86,87]. Galli and Brunori highlight some 
value-led terms such as 'traceability', 'social responsibility' and 'cultural identity' that can reveal people's motivations and actions to engage with SFSCs [88].

To build active community engagement in resilience building, decision makers benefit from facilitating shared control and responsibility for local food access with those who want it [21]. Utilizing policy that consults with and engages the broader community in decision making is central to local food contingency planning [89]. The International Association for Public Participation (IAP2) sets out the quality standards for engagement as a central part of decision making [90]. Some meanings associated with SFSCs, such as those predicated upon values such as 'environmentally sustainable' food systems, or the importance of 'food heritage,' are useful for eliciting motivations to invest community efforts in local food innovations, and for building food resilience. Much valuable information and meaningful action can be derived from the risk perceptions attached to such terms, those to whom they apply, and the lens through which the researcher or engagement practitioner investigates [91]. Building social capitals for a holistic approach to community health, such as feelings of social connectedness, belonging, trust and optimism, is not new [92].

\subsubsection{Priority 5: Focus on Communities Needing the Most Support}

The United Nations Food and Agriculture Organization (UN-FAO) advises meeting the needs of our most vulnerable as the pandemic is felt across countries globally [80]. The usual benchmarks for identifying the 'most vulnerable' in Australia due to pandemic impacts are becoming less obvious given the deepened inequalities from the loss of income [48]. This includes the associated increased pressure on food aid and food relief [93], and mental health impacts with higher levels of negative emotions in the general public such as anxiety, depression and stress [94]. One respondent stated that we must "anticipate the needs of people who do not know how to get help or ask for help". Australia's Foodbank Hunger Report (2020) identified from their study, during the initial onset of COVID-19, barriers to revealing the need for food assistance; these included feelings of embarrassment about peoples' negative view of them, and the shame of being perceived as inadequate and dependent on charity [14].

\subsection{Policy Implications for Local Food Access and Disaster Management: Addressing the Changing Status of 'Vulnerable'}

Considering the case study of Cairns Regional Council presented in this paper, local government authorities in developed countries grappling with disaster management and the care for the most vulnerable can be assisted with tailoring their own local food access agenda. In the following paragraphs we consider the changing status of what is conceptualized as 'vulnerable'. We are all potentially 'affected' in ways that may not be immediately obvious. Table 2 compares some examples of the most vulnerable members in Australian society who live with a persistent, chronic need for food relief, with the more transitory experience of food insecurity felt by a broader range of people during spiked and relatively shorter periods of food supply interruptions.

As illustrated in Table 2, temporary displacement and evacuations due to severe bushfire events give a sampled experience of a form of 'homelessness'. Likewise, a loss of employment or reduced job security due to pandemic-driven economic lockdowns has, in Australia, led to difficulties in paying housing rent and relying on food aid. With the increasing casualization of the workforce, these experiences are becoming more prolonged. 
Table 2. Comparison of some experiences between chronically vulnerable people and acute experiences from disaster impacts.

Transitory Food Insecurity: Some Examples of Common 'Spiked' Experiences from Disaster Impacts
Chronic Food Insecurity: Some Examples of Priority Vulnerable Members Living with Persistent Need for Support
- Evacuation

- Temporary displacement
- Homeless citizens

- $\quad$ People with little personal or family support

- People experiencing social isolation, neglect, or marginalization
- Having to rely on handouts, food aid and emergency relief

- Youth and children
- $\quad$ Citizens living with disabilities, chronic illness, ageing or infirmity
- Loss of employment

- $\quad$ Reduced job security
- Citizens residing in lower socio-economic neighborhoods

- $\quad$ Emerging casual workforce
- $\quad$ Feeling overwhelmed from multiple experiences and compounding stresses

- $\quad$ Recovery fatigue from ongoing impacts
- $\quad$ Groups with complex needs

- Indigenous citizens

- $\quad$ People for whom English is not the first spoken language

- All groups

Well-planned and anticipatory efforts may see most Australian individuals described as 'unaffected' (Department of Home Affairs 2018). However, experiencing the consequences of disaster events can lead to reduced capacities and a reduced sense of well-being in ways that may not seem obvious. For example, witnessing or hearing of distressing events [95], such as the 2011 Queensland Floods, lead to emotional costs from anniversaries that trigger trauma memories [96]. More recently, the anxieties of going without food and facing the unknown were evident globally during COVID-19 pandemic conditions, as were their effects on panic buying [82,97]. This behavior is a valuable indicator of stress points in the 'just-in-time' food supply chain [11]. Panic buying is highlighted amongst an ongoing and largely unseen chronic fatigue experienced from repeated experiences of having to bounce back from adversity [98], such as prolonged drought or periodic monsoonal events on Australian farming communities (for example, [99]). These kinds of experiences are potentially life-shaping and it is important to not assume that anyone is 'unaffected' [100], as engendering divisions between 'affected' and 'unaffected' can lead to "well-meaning but poorly planned" interventions [95] (p. 5). A key action when focusing on those needing the most support, therefore, is to discern the specific needs of specific places, including finding the 'hidden' food vulnerabilities that need support and harnessing the 'less tangible' motivations that underpin peoples' aspirations and feelings of self-efficacy [101]. Enabling broader access to SFSCs enables multiple resilience agendas. The social and geographical proximities for SFSCs provide more contextualized opportunities than a mere sense of satisfaction from engaging in pro-environmental purchasing choices [102]. They can encourage a sense of place and belonging. Food is no longer just something we consume, but is a reflection of our personal and collective identities as part of a greater whole-socially, culturally, economically and environmentally. Efforts to fill gaps in knowledge about what resilience means and could mean is an ongoing process [103]. Policy makers working on SFSC policy can team together with disaster management policy makers to create benefits to address all agendas. In this way, a holistic approach embeds a variety of perspectives to illustrate a variety of avenues for building multiple resiliencies [104-107]. 


\section{Conclusions}

While considering the context of developed countries, we have worked through a disaster risk management context to locally support food resilience within the far northeastern region of Australia. Cairns experiences a high prevalence of existing, chronic and intergenerationally entrenched food disadvantage. With the onset of COVID-19, and like the rest of the nation, Cairns has newly emerging food vulnerabilities, experienced by many for the first time.

The Australian Bureau of Agricultural and Resource Economics and Sciences (ABARES) reassures us that the 'business-as-usual' model of Australia's food security is fine the way it is, and that nationally, we will prosper with our current food supply model [108]. Such advice overlooks the impact that pandemic-driven mobility restrictions and lockdowns have upon farmers, processors, retailers, sellers and consumers within the overall food supply chain, and the 'ripple effects' that impact wellbeing in times of food shortages and the years beyond. It also overlooks the changing status of food 'vulnerability' in wealthy countries.

Responding directly to the research question, the Cairns case study demonstrates an active commitment to the spirit of the shared responsibility framework, which has the scope to place local food access as a connector for better anticipation and, therefore, planning for prevention, preparedness, response and recovery.

By offering our 'Local Food Access Model' the end-user decision-support needs of other local government authorities may consider our five strategic priorities for their own local and regional food needs and contexts. The inclusion of local food considerations within a local government's strategic priorities for disaster management can support decision making for accessing a wider range of SFSC options. Having a Plan B and a Plan $\mathrm{C}$ to access food locally is a necessity if the shared responsibility framework embodied by disaster management is to be effective in facilitating adaptive capacities to multiple and ongoing disruptions. For local government authorities, having options is also about having choice about the contribution that food makes to regional communities and economic wellbeing, spanning local production to processing, retailing and distribution.

Author Contributions: Conceptualization, K.R., C.D., S.C. and P.L.; methodology, K.R., C.D., S.C. and P.L.; formal analysis, K.R., C.D. and S.C.; investigation, K.R., C.D. and S.C.; data curation, K.R., C.D., S.C. and P.L.; writing-original draft preparation, K.R.; writing-review and editing, K.R., C.D., S.C. and P.L.; visualization, K.R. and C.D.; supervision, K.R.; project administration, K.R. and S.C.; funding acquisition, K.R., C.D. and S.C. All authors have read and agreed to the published version of the manuscript.

Funding: This research was funded by the Cities Research Institute's "Pilot Project Industry Collaboration Scheme," Griffith University and the Queensland Government's "Monsoonal Trough Grant" (funding received by the Cairns Regional Council from the Queensland Reconstruction Authority).

Institutional Review Board Statement: The study was approved by the GRIFFITH UNIVERSITY Human Research Ethics Committee, Office for Research (Ethics reference number 2020/580, approved on 26 August 2020).

Informed Consent Statement: Informed consent was obtained from all subjects involved in the study.

Conflicts of Interest: There are no conflict of interest to declare. The funders had no role in the design of the study; in the collection, analyses, or interpretation of data; in the writing of the manuscript, or in the decision to publish the results.

\section{Appendix A. "Accessing Local Food in Cairns"-Online Survey and Telephone Interview Questions}

1. Your Organization

Q1: What is the name and location of your organization?

Q2: Please nominate which group you work with. (Check all that apply) 
Aged Care

Disability Services

Aboriginal Support

Youth Services

Homeless Assistance

Multicultural Assistance

Other

Q3: What location does your organization work in? (Check all that apply)

Babinda

Bungalow / Portsmith

Manoora/Manunda

Northern Beaches

Other

Q4: What are the main categories of service that your organization provides?

Q5: How many clients does your organization support? (Choose one of the following answers)

$1-50$

51-100

101-300

301-500

More than 501

Q6: The number of people seeking your services is ... (Choose one of the following answers)

Increasing

Consistent

Decreasing

1. Food Access Options

2. Food Access Options

Q7: What local food access options are you aware of that are available within the Cairns Region? (Check all that apply)

Direct delivery of fresh produce (e.g., Real Food Network, Food for Thought, Community Growers FNQ)

Direct from the farmer (e.g., visiting a local farm, Farmer Meets Foodie)

Food markets (e.g., Rusty's markets)

Bulk wholesale food outlets (e.g., Community Food)

Community gardens (e.g., Manoora Community Garden)

Food sharing (e.g., Food is Free Facebook, Cairns library facilities seed saving and sharing) Emergency supply, food aid and volunteer organizations (e.g., OzHarvest, Community Growers FNQ)

Home grown (e.g., household or workplace vegetable garden, household livestock)

O Other

Q8: What local food access options did you use during previous disaster events, including events such as bushfire, flooding, cyclone, storm surge events, and the COVID-19 pandemic? (Check all that apply)

Direct delivery of fresh produce (e.g., Real Food Network, Food for Thought, Community Growers FNQ)

Direct from the farmer (e.g., visiting a local farm, Farmer Meets Foodie)

Food markets (e.g., Rusty's markets)

Bulk wholesale food outlets (e.g., Community Food)

Community gardens (e.g., Manoora Community Garden)

Food sharing (e.g., Food is Free Facebook, Cairns library facilities seed saving and sharing) Emergency supply, food aid and volunteer organizations (e.g., OzHarvest, Community Growers FNQ) 
Home grown (e.g., household or workplace vegetable garden, household livestock)

○ Other

Q9: How likely are you to use the following options in future events? $(0=$ never, 4 = highly likely)

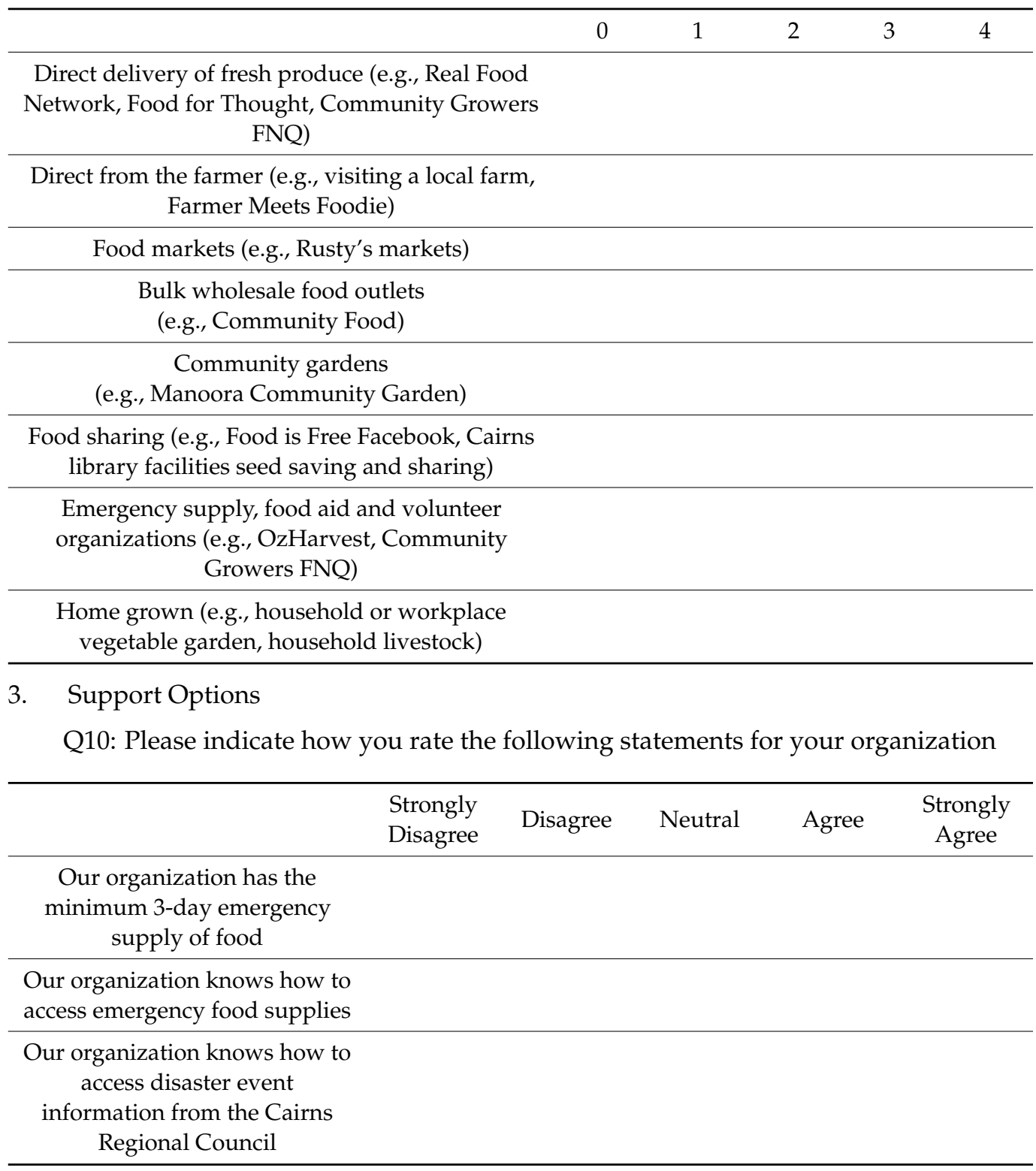

Q11: Please indicate how you rate the following statements for your clients

\begin{tabular}{|c|c|c|c|c|c|}
\hline & $\begin{array}{l}\text { Strongly } \\
\text { Disagree }\end{array}$ & Disagree & Neutral & Agree & $\begin{array}{l}\text { Strongly } \\
\text { Agree }\end{array}$ \\
\hline $\begin{array}{l}\text { Our clients have the minimum } \\
\text { 3-day emergency supply of food }\end{array}$ & & & & & \\
\hline $\begin{array}{l}\text { Our clients know how to access } \\
\text { emergency food supplies }\end{array}$ & & & & & \\
\hline $\begin{array}{l}\text { Our clients know how to access } \\
\text { disaster event information from } \\
\text { the Cairns Regional Council }\end{array}$ & & & & & \\
\hline
\end{tabular}


Q12: Scenario 1: There is a second wave of COVID-19 in the Cairns Region. This has resulted in limited access to food, more calls for social distancing and added measures to reduce the spread. What additional food support and services should be available to your organization?

Q13: Scenario 2: The Cairns Region is experiencing a cyclone and pandemic at the same time. This has resulted in limited access to food and damage to buildings including houses and shopping centers. What additional food support and services should be available to the clientele that your organization supports?

Q13: How can the Cairns Regional Council support your organization's access to local food? (Check all that apply)

Support social connection activities and events (e.g., local food festivals)

Map the local food access locations in the region

Workshops on food preparation, nutrition, access and sharing

Raise awareness of the need for accessing local food

Build a broader community harden hub

Develop an online platform of all local food access agencies, apps and groups

Develop more community-food-sharing locations (e.g., food pantries)

Show how to access emergency food options on the Cairns Disaster Dashboard

Other

Q14: In support of your responses from above, what communication methods would be useful for your organization, from the Cairns Regional Council? (Check all that apply)

Email

Text message

Letter box information sheets

Local newspaper

Television

Radio

Social media

Cairns Regional Council website/Disaster Dashboard

Public interactions (e.g., shopping center information booths)

Other

Q15: In support of your responses from above, what communication methods would be useful for your clients, from the Cairns Regional Council? (Check all that apply)

Email

Text message

Letter box information sheets

Local newspaper

Television

Radio

Social media

Cairns Regional Council website/Disaster Dashboard

Public interactions (e.g., shopping center information booths)

Other

Q16: Are there any more ideas that have not been covered that you would like to comment on?

\section{References}

1. Clapp, J.; Cohen, M. The Global Food Crisis: Governance Challenges and Opportunities; Wilfrid Laurier University Press: Waterloo, ON, Canada, 2009; ISBN 978-1-55458-198-6.

2. United Nations-Food and Agriculture Organization (UN-FAO). The State of Food Security and Nutrition in the World. Available online: https:/ /www.fao.org/publications/sofi/2021/en/ (accessed on 10 November 2021).

3. Long, M.; Goncalves, L.; Stretesky, P.; Defeyter, M. Food insecurity in advanced Capitalist Nations: A review. Sustainability 2020, 12, 3654. [CrossRef] 
4. Riches, G.; Silvasti, T. Hunger in the rich world: Food aid and right to food perspectives. In First World Hunger Revisited; Riches, G., Silvasti, T., Eds.; Palgrave Macmillan: London, UK, 2014; pp. 1-14.

5. Hossain, M.; Long, M.; Stretesky, P. Welfare state spending, income inequality and food insecurity in affluent Nations: A cross-national examination of OECD countries. Sustainability 2021, 13, 324. [CrossRef]

6. Bene, C. Resilience of local food systems and links to food security: A review of some important concepts in the context of COVID-19 and other shocks. Food Secur. 2020, 12, 805-822. [CrossRef] [PubMed]

7. Cappelli, A.; Cini, E. Will the COVID-19 pandemic make us reconsider the relevance of short food supply chains and local productions? Trends Food Sci. Technol. 2020, 99, 566-567. [CrossRef] [PubMed]

8. Farcas, A.; Galanakis, C.; Socaciu, C.; Pop, O.; Tibulca, D.; Paucean, A.; Jimborean, M.; Fogarasi, M.; Salanta, L.; Tofana, M.; et al. Food Security during the pandemic and the importance of the bioeconomy in the new era. Sustainability 2021, 13, 150. [CrossRef]

9. Marusak, A.; Sadeghiamirshahidi, N.; Krejci, C.; Mittal, A.; Beckwith, S.; Cantu, J.; Morris, M.; Grimme, J. Resilient regional food supply chains and rethinking the way forward: Key takeaways from the COVID-19 pandemic. Agri. Syst. 2021, $190,102101$. [CrossRef]

10. Herrington, A.; Mix, T. Invisible and insecure in rural America: Cultivating dignity in local food security initiatives. Sustainability 2021, 13, 3109. [CrossRef]

11. Power, M.; Doherty, B.; Pybus, K.; Pickett, K. How COVID-19 has exposed inequalities in the UK food system: The case of UK food and poverty. Emerald Open Res. 2020, 2, 1-22. [CrossRef]

12. Stretesky, P.; Defeyter, M.; Long, M.; Ritchie, L.; Gill, D. Holiday hunger and parental stress: Evidence from north east England. Sustainability 2020, 12, 4141. [CrossRef]

13. Commonwealth of Australia. Royal Commission into National Natural Disaster Arrangements Report; Report 28 October 2020. ISBN: 978-1-921091-46-9. Available online: https:/ / naturaldisaster.royalcommission.gov.au/publications/royal-commissionnational-natural-disaster-arrangements-report (accessed on 18 January 2022).

14. FoodBank Australia. Hunger Report 2020: Food Insecurity in the Time of COVID-19. Available online: https://www.foodbank. org.au/wp-content/uploads/2020/10/QLD_HungerReport_2020.pdf?state=qld (accessed on 23 November 2021).

15. Atkinson, C.; Curnin, S. Sharing responsibility in disaster management policy. Prog. Disaster Sci. 2020, 7, 100122. [CrossRef]

16. Council of Australian Governments (COAG). National Strategy for Disaster Resilience. Available online: https://knowledge.aidr. org.au/media/2153/nationalstrategyfordisasterresilience.pdf (accessed on 23 November 2021).

17. United Nations Office for Disaster Risk Reduction (UNDRR). Sendai Framework for Disaster Risk Reduction. Available online: https:/ / www.preventionweb.net/files/43291_sendaiframeworkfordrren.pdf (accessed on 23 November 2021).

18. United Nations Office for Disaster Risk Reduction (UNDRR). Global Assessment Report on Disaster Risk Reduction: GAR19 Distilled. Available online: https://gar.undrr.org/sites/default/files/gar19distilled.pdf (accessed on 23 November 2021).

19. Oktari, R.; Idroes, R.; Sofyan, H.; Munadi, K.; Syamsidik. City resilience towards coastal hazards: An integrated bottom-up and top-down assessment. Water 2020, 12, 2823. [CrossRef]

20. Parsons, M.; Glavac, S.; Hastings, P.; Marshall, G.; McGregor, J.; McNeill, J.; Morley, P.; Reeve, I.; Stayner, R. Top-down assessment of disaster resilience: A conceptual framework using coping and adaptive capacities. Int. J. Disaster Risk Reduct. 2016, 19, 1-11. [CrossRef]

21. Reis, K. Five things government can do to encourage local food contingency plans. J. Environ. Plan. Manag. 2019, 62, 2295-2312. [CrossRef]

22. Queensland Reconstruction Authority (QRA). Our Work. 2021. Available online: https://www.qra.qld.gov.au/about-us/ourwork (accessed on 24 November 2021).

23. Reis, K.; Desha, C. Closing the loop on local food access through disaster management. In The Palgrave Encyclopedia of Urban and Regional Futures; Brears, R., Ed.; Palgrave Macmillan: Cham, Switzerland, 2021. [CrossRef]

24. United Nations-Food and Agriculture Organization (UN-FAO). FAO + Australia-Promoting Prosperity. Reducing Poverty. Enhancing Stability. Available online: https:/ / www.fao.org/documents/card/en/c/CA3026EN (accessed on 10 November 2021).

25. Greenville, J.; McGilvray, H.; Cao, L.; Fell, J. Impacts of COVID-19 on Australian Agriculture, Forestry and Fisheries Trade; Research Report 20.11. Australian Bureau of Agricultural and Resource Economics and Sciences. 2020. Available online: https:/ / daff.ent.sirsidynix.net.au/client/en_AU/search/asset/1030221/0 (accessed on 18 January 2022).

26. Commonwealth of Australia. Living on the Edge: Inquiry Into Intergenerational Welfare Dependence Final Report; House of Representatives Select Committee on Intergenerational Welfare Dependence. 2019. Available online: https://www.aph.gov.au/ Parliamentary_Business /Committees/House/Former_Committees/Intergenerational_Welfare_Dependence/IGWD/Final_ Report (accessed on 18 January 2022).

27. Australian Institute of Family Studies. Food Insecurity in Australia: What Is It, Who Experiences It and How Can Child and Family Services Support Families Experiencing It? CAFCA Practice Sheet August. Available online: https://aifs.gov.au/cfca/ publications / food-insecurity-australia-what-it-who-experiences-it-and-how-can-child (accessed on 28 November 2021).

28. Reis, K.; Desha, C.; Bailey, M.; Liddy, P.; Campbell, S. Towards Local Food Resilience Key Considerations for Building Local Food Resilience and Contingency Plans: A Focus on the Cairns Region. Final Report, 26 March 2021. Available online: https:// www.griffith.edu.au/_data/assets/pdf_file/0029/1334297/CRI-Towards-local-food-resilience-research-report.pdf (accessed on 27 November 2021). 
29. Lindberg, R.; Whelan, J.; Lawrence, M.; Gold, L.; Friel, S. Still serving hot soup? Two hundred years of a charitable food sector in Australia: A narrative review. Aust. N. Z. J. Public Health 2015, 39, 358-365. [CrossRef] [PubMed]

30. Landrigan, T.; Kerr, D.; Dhaliwal, S.; Pollard, C. Protocol for the development of a Food Stress Index to identify households most at risk of food insecurity in Western Australia. Int. J. Environ. Res. Public Health 2019, 16, 79. [CrossRef]

31. Cairns Regional Council. Cairns Pathway to Recovery from COVID-19. Available online: https://www.cairns.qld.gov.au/_ data/assets/pdf_file/0007/342574/PathwayCovidRecovery_16_6.pdf (accessed on 27 November 2021).

32. Henriques-Gomes, L. Australian Food Banks Report Huge Surge in Demand During COVID Pandemic. The Guardian, 12 October 2020. Available online: https://www.theguardian.com/australia-news/2020/oct/12/australian-food-banks-report-huge-surgein-demand-during-covidpandemic (accessed on 28 November 2021).

33. Phillips, V.; Gray, M.; Biddle, N. COVID-19 JobKeeper and JobSeeker Impacts on Poverty and Housing Stress under Current and Alternative Economic and Policy Scenarios; Australian National University. 2020. Available online: https:/ / csrm.cass.anu.edu.au/sites/default/files/docs/2020/8/Impact_of_Covid19_JobKeeper_and_Jobeeker_measures_on_ Poverty_and_Financial_Stress_FINAL.pdf (accessed on 29 November 2021).

34. Babacan, H.; McHugh, J.; Dale, A. Cairns Local COVID-19 Rapid Social Needs Assessment; The Cairns Institute, 2020. ISBN 978-0-6489220-0-1. Available online: https:/ / www.cairns.qld.gov.au/_data/assets/pdf_file/0008/398204/CRC-Covid-RapidSocial-Needs-v.5-22-Sept-2020.pdf (accessed on 18 January 2022).

35. Schofield, H.; Twigg, J. Making Cities Sustainable and Resilient: Lessons Learned from the Disaster Resilience Scorecard Assessment and Disaster Risk Reduction (DRR) Action Planning. Available online: https://www.preventionweb.net/files/6641 3_undrrlessonslearnedfromdevcoproject.pdf (accessed on 27 November 2021).

36. United Nations Office for Disaster Risk Reduction (UNDRR). Making Cities Resilient: My City Is Getting Ready (MCR2030). Available online: https:/ / www.unisdr.org/campaign/resilientcities/home/article/making-cities-resilient-2030-mcr2030-initialproposal (accessed on 23 November 2021).

37. Cairns Regional Council. Be Ready Cairns! 2019-2024: Five Year Resilience Strategy; Internal Management Document; Disaster Management Unit: Cairns, QLD, Australia, 2019.

38. Google Maps. Cairns. Available online: https://www.google.com/maps/@-16.9790099,145.7072285,10.06z (accessed on 28 November 2021).

39. Australian Bureau of Statistics (ABS). 2033.0.55.001-Census of Population and Housing: Socio-Economic Indexes for Areas, 2016. Available online: https:/ / www.abs.gov.au/websitedbs/censushome.nsf/home/seifa (accessed on 23 November 2021).

40. Geoscience Australia. Climate Extremes. Available online: http://www.ga.gov.au/scientific-topics/national-locationinformation/dimensions / climatic-extremes (accessed on 23 November 2021).

41. Australian Bureau of Statistics (ABS). 2033.0.55.001-Census of Population and Housing: Advantage and Disadvantage: The Concepts, 2016. Available online: https:/ /www.abs.gov.au/ausstats/abs@.nsf/Lookup/by\%20Subject/2033.0.55.001 \{\}2016 \{\}Main\%20Features \{\}Advantage\%20\&\%20Disadvantage:\%20The\%20Concepts \{\}9 (accessed on 23 November 2021).

42. Food Security Information Network (FSIN). 2020 Global Report on Food Crises: Joint Analysis for Better Decisions. Available online: https:/ / ebrary.ifpri.org/utils/getfile/collection/p15738coll2/id/133693/filename/133904.pdf (accessed on 18 January 2022).

43. McKay, F.; Haines, B.; Beswick, H.; McKenzie, H.; Lindberg, R. The prevalence, severity and experience of food insecurity in Australia: An investigation of food aid use. Health Soc. Care 2020, 28, 2399-2407. [CrossRef]

44. Biddle, N.; Edwards, B.; Gray, M.; Sollis, K. Hardship, Distress, and Resilience: The Initial Impacts of COVID-19 in Australia, (ANUPoll \#33). Available online: https://openresearch-repository.anu.edu.au/handle/1885/213194 (accessed on 28 November 2021).

45. Janda, M.; Lasker, P. Australian Recession Confirmed as COVID-19 Triggers Biggest Economic Plunge on Record. ABC News, 3 September 2020. Available online: https:/ / www.abc.net.au/news/2020-09-02/australianrecession-confirmed-as-economyshrinks-in-june-qtr/12619950 (accessed on 25 November 2021).

46. Murphy, K. Australia's Economy Was Aready Weak and the Coronavirus Pandemic has Belted it Into Recession. The Guardian, 2 September 2020. Available online: https:/ / www.theguardian.com/business/2020/sep/02/australias-economy-was-alreadyweak-and-the-coronavirus-pandemic-has-belted-it-into-recession (accessed on 28 November 2020).

47. Cullen, M. COVID-19 and the Risk to Food Supply Chains: How to Respond? Food and Agriculture Organization of the United Nations. Available online: http:/ / www.fao.org/3/ca8388en/CA8388EN.pdf (accessed on 28 November 2021).

48. Kent, K.; Murray, S.; Penrose, B.; Auckland, S.; Visentin, D.; Godrich, S.; Lester, E. Prevalence and socio-demographic predictors of food insecurity in Australia during the COVID-19 pandemic. Nutrients 2020, 12, 2682. [CrossRef]

49. Puppazoni, R.; Janda, M. Unemployment Doesn't Look So Bad as 6.9pc, But the Reality for Job Seekers is Far Grimmer. ABC News, 15 October 2020. Available online: https:/ /www.abc.net.au/news/2020-10-15/unemployment-jobs-underemploymentseptember-abs/12767556 (accessed on 26 November 2021).

50. Lloyd, P.; Dixon, R. Modelling the spread of the coronavirus: A view from economics. Aust. Econ. Rev. 2021, 54, 1-21. [CrossRef]

51. Riga, R. Coronavirus and Queensland's Health System: Just How Costly Will the Pandemic Be into the Future? ABC News, 15 September 2020. Available online: https: / www.abc.net.au/news / 2020-09-15/queensland-how-much-will-coronavirus-costhealth-system/12661672 (accessed on 27 November 2021). 
52. Stead, V. Australia's Food Supply Relies on Migrant Workers Who are Facing Coronavirus Limbo. The Guardian, 24 March 2020. Available online: https:/ / www.theguardian.com/world/commentisfree/2020/mar/24/australias-food-supply-relieson-migrant-workers-who-are-facing-coronavirus-limbo (accessed on 25 November 2021).

53. Sullivan, K. Farmers Fear Worker Shortage Due to COVID-19 Restrictions Despite Rising Unemployment, ABC News, 30 July 2020. Available online: https:/ / www.abc.net.au/news/rural/2020-07-30/farm-labour-shortage-feared-due-to-coronavirus-controls / 12504802 (accessed on 26 November 2021).

54. Dufty, N.; Martin, P.; Zhao, S. Demand for Farm Workers: ABARES Farm Surveys. Available online: https://www.agriculture. gov.au/abares/research-topics/labour/labour-survey-2018 (accessed on 28 November 2021).

55. Dawes, S. Coronavirus Panic Buying Triggers Supermarket Price Hikes as Retailers Plead For Calm. ABC News, 22 March 2020. Available online: https:/ / www.abc.net.au/news/2020-03-22/coronavirus-panic-buying-sees-fresh-produce-price-hikes / 1207 8198 (accessed on 28 November 2021).

56. Botha, F.; de New, J.; de New, S.; Ribar, D.; Salamanca, N. Implications of COVID-19 labour market shocks for inequality in financial wellbeing. J. Pop. Econ. 2021, 34, 655-689. [CrossRef]

57. O'Kane, G. COVID-19 puts the spotlight on food insecurity in rural and remote Australia. Aust. J. Rural Health 2020, 28, 319-320. [CrossRef]

58. Funnell, A. The Hidden Impact of the Coronavirus Pandemic Is Rising Urban Inequality. ABC News, 26 November 2020. Available online: https://www.abc.net.au/news/2020-11-26/hidden-impact-of-coronavirus-covid-19-pandemic-urbaninequality / 12903388 (accessed on 27 November 2021).

59. FoodBank Australia. Hunger Report 2021. Available online: https:/ / reports.foodbank.org.au/foodbank-hunger-report-2021/? state $=$ qld (accessed on 18 January 2022).

60. Seivwright, A.; Callis, Z.; Flatau, P. Food insecurity and socioeconomic disadvantage in Australia. Int. J. Environ. Res. Public Health 2020, 17, 559. [CrossRef]

61. Goetze, E. Australian Charities Heading for 'Funding Cliff' When COVID-19 Job Support Ends. ABC News, 3 June 2020. Available online: https://www.abc.net.au/news/2020-06-03/charities-funding-shortfall-covid-jobkeeper-ends/12313630 (accessed on 27 November 2021).

62. Tuffield, R. COVID-19 Putting Food Charities and the Homeless Under Extreme Pressure. ABC News, 21 March 2020. Available online: https://www.abc.net.au/news/2020-03-21/homelessness-charities-hard-hit-by-covid-19-pandemic/12071758 (accessed on 24 November 2021).

63. Shakespeare-Finch, J.; Bowen-Salter, H.; Cashin, M.; Badawi, A.; Wells, R.; Rosenbaum, S.; Steel, Z. COVID-19: An Australian perspective. J. Loss Trauma 2020, 25, 662-672. [CrossRef]

64. Fitzgerald, D.; Nunn, K.; Isaacs, D. Consequences of physical distancing emanating from the COVID-19 pandemic: An Australian perspective. Paed. Resp. Rev. 2020, 35, 25-30. [CrossRef]

65. Scott, S.; Kinsella, E. Mental Health and COVID-19: How the Coronavirus Is Affecting Our Way of Life. ABC News, 18 April 2020. Available online: https: / / www.abc.net.au/news/2020-04-18/mental-health-and-coronavirus-how-australia-is-reactingcovid19/12159750 (accessed on 27 November 2021).

66. Dalzell, S. Australia Creates New Deputy Chief Medical Officer Position Amid Coronavirus Mental Health Fears. ABC News, 13 May 2020. Available online: https:/ / www.abc.net.au/news/2020-05-13/australia-deputy-chief-medical-officer-coronavirusmental-health/12241264 (accessed on 28 November 2021).

67. Bartone, T.; Hickie, I.; McGorry, P. Joint Statement-COVID-19 Impact Likely to Lead to Increased Rates of Suicide and Mental Illness. Australian Medical Association, 7 May 2020. Available online: https:/ / ama.com.au/media/joint-statement-covid-19 -impact-likely-lead-increased-rates-suicide-and-mental-illness (accessed on 28 November 2021).

68. Jarzębowski, S.; Bourlakis, M.; Bezat-Jarzębowska, A. Supply chains (SFSC) as local and sustainable systems. Sustainability 2020, 12, 4715. [CrossRef]

69. Birtalan, I.; Bartha, A.; Neulinger, A.; Bardos, G.; Olah, A.; Racz, J.; Rigo, A. Community supported agriculture as a driver of food-related well-being. Sustainability 2020, 12, 516. [CrossRef]

70. Brown, E.; Dury, S.; Holdsworth, M. Motivations of consumers that use local, organic fruit and vegetable box schemes in central England and southern France. Appetite 2009, 53, 183-188. [CrossRef]

71. Parashar, S.; Sood, G.; Agrawal, N. Modelling the enablers of food supply chain for reduction in carbon footprint. J. Clean. Prod. 2020, 275, 122932. [CrossRef]

72. Diehl, J. Growing for Sydney: Exploring the urban food system through farmers' social networks. Sustainability 2020, $12,3326$. [CrossRef]

73. Rucabado-Palomar, T.; Cuéllar-Padilla, M. Short food supply chains for local food: A difficult path. Renew. Agric. Food Syst. 2020, 35, 182-191. [CrossRef]

74. Kummer, S.; Milestad, R. The diversity of organic box schemes in Europe: An exploratory study in four countries. Sustainability 2020, 12, 2734. [CrossRef]

75. Booth, S.; Pollard, C.; Coveney, J.; Goodwin-Smith, I. 'Sustainable' rather than 'subsistence' food assistance solutions to food insecurity: South Australian recipients' perspectives on traditional and social enterprise models. Int. J. Environ. Res. Public Health 2018, 15, 2086. [CrossRef] 
76. Bazzani, C.; Canavari, M. Alternative Agri-Food Networks and Short Food Supply Chains: A Review of the Literature. Econ. Agro-Aliment. 2013, 15, 11-34. Available online: http://www.francoangeli.it/riviste/Scheda_Rivista.aspx?IDArticolo=49559\& Tipo=ArticoloPDF (accessed on 29 November 2021). [CrossRef]

77. Lamine, C. Settling shared uncertainties: Local partnerships between producers and consumers. Sociol. Rural. 2005, 45, 324. [CrossRef]

78. Hartley, A.; Hughes, M. Farmers Enjoy Fivefold Rise in Food Sales as Coronavirus Drives More People to Avoid Supermarkets. ABC News, 5 April 2020. Available online: https:/ /www.abc.net.au/news/2020-04-05/farmers-rising-food-sales-gatecoronavirus/12119368 (accessed on 29 November 2021).

79. Todorovic, V.; Maslaric, M.; Bojic, S.; Jokic, M.; Mircetic, D.; Nikolicic, S. Solutions for more sustainable distribution in the short food supply chains. Sustainability 2018, 10, 3481. [CrossRef]

80. United Nations-Food and Agriculture Organization (UN-FAO). Urban Food Systems and COVID-19: The Role of Cities and Local Governments in Responding to the Emergency. Available online: http://www.fao.org/3/cb0407en/CB0407EN.pdf (accessed on 10 November 2021).

81. Howes, M.; Tangney, P.; Reis, K.; Grant-Smith, D.; Heazle, M.; Bosomworth, K.; Burton, P. Towards networked governance: Improving interagency communication and collaboration for disaster risk management and climate change adaptation in Australia. J. Environ. Plan. Manag. 2015, 58, 757-776. [CrossRef]

82. Reis, K.; Desha, C.; Burton, P. We've Had a Taste of Disrupted Food Supplies: Here Are 5 Ways We Can Avoid a Repeat. The Conversation, 4 May 2020. Available online: https:/ / theconversation.com/weve-had-a-taste-of-disrupted-food-supplies-hereare-5-ways-we-can-avoid-a-repeat-135822 (accessed on 27 November 2021).

83. Australian Institute for Disaster Resilience (AIDR). Community Engagement for Disaster Resilience. Available online: https: // knowledge.aidr.org.au/resources/handbook-community-engagement/ (accessed on 23 November 2021).

84. Granheim, S.; Løvhaug, A.; Terragni, L.; Torheim, L.; Thurston, M. Mapping the digital food environment: A systematic scoping review. Obes. Rev. 2021, 23, 1-18. [CrossRef]

85. Edwards, F.; Davies, A. Connective consumptions: Mapping Melbourne's food sharing ecosystem. Urban Policy Res. 2018, 36 , 476-495. [CrossRef]

86. Galli, F.; Bartolini, F.; Brunori, G. Handling diversity of visions and priorities in food chain sustainability assessment. Sustainability 2016, 8, 305. [CrossRef]

87. Vermeulen, W.; Kok, M. Government interventions in sustainable supply chain governance: Experience in Dutch front-running cases. Ecol. Econ. 2021, 83, 183-196. [CrossRef]

88. Galli, F.; Brunori, G. Short Food Supply Chains as Drivers of Sustainable Development: Evidence Document; FOODLINKS (GA No. 265287). 2013. ISBN 978-88-90896-01-9. Available online: https://orgprints.org/id/eprint/28858/1/evidence-documentsfsc-cop.pdf (accessed on 18 January 2022).

89. Reis, K.; Desha, C.; Rifai, A. Planning for food contingencies: A call to action. Aust. J. Emerg. Manag. 2019, $34,14-15$.

90. International Association for Public Participation (IAP2). Quality Assurance Standard: For Community and Stakeholder Engagement. IAP2 Australasia. Available online: https://iap2.org.au/wp-content/uploads/2019/07/IAP2_Quality_Assurance_ Standard_2015.pdf (accessed on 23 November 2021).

91. Beck, U. From industrial society to the risk society: Questions of survival, social structure and ecological enlightenment. Theory Cult. Soc. 1992, 9, 97-123. [CrossRef]

92. Matthews, V.; Longman, J.; Bennett-Levy, J.; Braddon, M.; Passey, M.; Bailie, R.; Berry, H. Belonging and inclusivity make a resilient future for all: A cross-sectional analysis of post-flood social capital in a diverse Australian rural community. Int. J. Environ. Res. Public Health 2020, 17, 7676. [CrossRef]

93. McKay, F.; Bastian, A.; Lindberg, R. Exploring the response of the Victorian emergency and community food sector to the COVID-19 pandemic. J. Hunger Environ. Nutr. 2021, 16, 447-461. [CrossRef]

94. Rossell, S.; Neill, E.; Phillipou, A.; Tan, E.; Toh, W.; Van Rheenen, T.; Meyer, D. An overview of current mental health in the general population of Australia during the COVID-19 pandemic: Results from the COLLATE project. Psychiatry Res. 2021, $296,113660$. [CrossRef] [PubMed]

95. Department of Home Affairs. Community Recovery Handbook 2: Australian Disaster Resilience Handbook Collection. Available online: https:/ / knowledge.aidr.org.au/media/5634/community-recovery-handbook.pdf (accessed on 23 November 2021).

96. White, J. Queensland Floods 2011: Counting Emotional Costs of 2011 Flood Emergency. Brisbane Times, 8 January 2016. Available online: https: / www.brisbanetimes.com.au/national/queensland/queenslanders-still-counting-emotional-cost-of2011-flood-emergency-20160108-gm2b4f.html (accessed on 28 November 2021).

97. Norberg, M.; Rucker, D. Psychology Can Explain Why Coronavirus Drives Us to Panic Buy. It Also Provides Tips on How to Stop. The Conversation, 30 March 2020. Available online: https: / theconversation.com/psychology-can-explain-why-coronavirusdrives-us-to-panic-buy-it-also-provides-tips-on-how-to-stop-134032 (accessed on 28 November 2020).

98. Sanders, D.; Laing, J.; Frost, W. Exploring the role and importance of post-disaster events in rural communities. J. Rural Stud. 2015, 41, 82-94. [CrossRef]

99. Fennell, K.; Jarrett, C.; Kettler, L.; Dollman, J.; Turnbull, D. Watching the bank balance build up then blow away and the rain clouds do the same: A thematic analysis of south Australian farmers' sources of stress during drought. J. Rural Stud. 2016, 46, 102-110. [CrossRef] 
100. Australian Red Cross. Communicating in Recovery. Available online: https://www.redcross.org.au/getmedia/2810a05a-3327-4 7f4-8a2a-7e89c14e2335/Communicating-in-recovery-resource.pdf.aspx (accessed on 23 November 2021).

101. Bene, C.; Frankenberger, T.; Griffin, T.; Langworthy, M.; Mueller, M.; Martin, S. 'Perception matters': New insights into the subjective dimension of resilience in the context of humanitarian and food security crises. Prog. Devel. Stud. 2019, 19, 186-210. [CrossRef]

102. Paciarotti, C.; Torregiani, F. The logistics of the short food supply chain: A literature review. Sustain. Prod. Cons. 2021, 26, 428-442. [CrossRef]

103. Marchese, D.; Reynolds, E.; Bates, M.; Morgan, H.; Spierre Clark, S.; Linkov, I. Resilience and sustainability: Similarities and differences in environmental management applications. Sci. Total Environ. 2018, 613-614, 1275-1283. [CrossRef]

104. Cattivelli, V.; Rusciano, V. Social innovation and food provisioning during COVID-19: The case of urban-rural initiatives in the Province of Naples. Sustainability 2020, 12, 4444. [CrossRef]

105. Cvijanović, D.; Ignjatijević, S.; Tankosić, J.; Cvijanović, V. Do local food products contribute to sustainable economic development? Sustainability 2020, 12, 2447. [CrossRef]

106. Pulighe, G.; Lupia, F. Food first: COVID-19 outbreak and cities lockdown a booster for a wider vision on urban agriculture. Sustainability 2020, 12, 5012. [CrossRef]

107. Hecht, A.; Biehl, E.; Barnett, D.; Neff, R. Urban food supply chain resilience for crises threatening food security: A qualitative study. J. Acad. Nutr. Diet 2020, 119, 211-224. [CrossRef] [PubMed]

108. Hatfield-Dodds, S.; Gooday, P. Don't Panic: Australia Has Truly Excellent Food Security. The Conversation, 1 May 2020. Available online: https://theconversation.com/dont-panic-australia-has-truly-excellent-food-security-136405 (accessed on 28 November 2021). 